\title{
CURRENT LITERATURE IN EXPERIMENTAL PSYCHOLOGY
}

\section{METHODS \& INSTRUMENTATION}

Clirry, R. E. (M.I.T. Cambridge, Mass. 02139). A random search algorithm for laboratory computers. Behavior Research Methods \& Instrumentation, 1975, 7, 369-376.

Litrle, W. A. (Physics Dept., Stanford Univ., Stanford, Calif. 94305). \& Shaw, G. L. A statistical theory of short and long term memory. Behavioral Biology, 1975, 14, 115-133.

\section{METHODS AND DESIGNS}

Choе, C. S. (Univ. of Kansas, Lawrence, Kans. 66045), Welch, R. B., Gilford, R. M., \& Juola, J. R. The "ventriloquist effect": Visual dominance or response bias? Perception \& Psychophysics, 1975, 18, 55-60.

GeEN, R. G. (Univ. of Missouri. Columbia, Mo. 65201), \& Stonner, D. Primary associates to 20 verbs connoting violence. Behavior Research Methods \& Instrumentation, 1975. 7. 391-392.

Goldstein, M. L. (Indiana Univ. Kokomo, Ind. 46901). A simple method for making small lesions in the limbic system of the white rat. Bulletin of the Psychonomic Society, $1975,6,67-68$.

Klitzner, M. D. (Univ. of California, San Diego, La Jolla, Calif. 92037). Hedonic integration: Test of a linear model. Perception \& Psychophysics, 1975, 18. 49-54.

Krebs, W. (Institut für Neurobiologie, KFA, 517 Jülich, Germany, Helrich, C. S.. \& Wulff, V. J. The role of restricted extracellular compartments in vision. Vision Research, 1975. 15, 767-770.

Levine, M. W. (Univ. of Illinois at Chicago Circle, Box 4348, Chicago, Ill. 60680), \& Abramov, I. An analysis of spatial summation in the receptive fields of goldfish retinal ganglion cells. Vision Research, 1975, 15, 777-789.

Navon. D. (Univ. of Haifa, Haifa 31999. Israel). A simple method for latency analysis in signal detection tasks. Perception \& Psychophysics, 1975, 18, 61-64.

Povel, D.-J. (Univ. of Nijmegen, Erasmuslaan 16, Nijmegen, The Netherlands). Development of a vowel corrector for the deat. Psychological Research, 1974, 37, 51-70.

Roland, P. E. (Neurol. Dept. N 2082, Rigshospitalet, Blegdamsvej 9, 2100 0. Copenhagen, Denmark). Some principles and new methods of tactile stimulation. Behavior Research Methods \& Instrumentation, 1975, 7, 333-338.

\section{INSTRUMENTATION AND TECHNIQUES}

Cerf-BeARE, A. (Univ. of Maryland Baltimore County, Baltimore, Md. 21228), \& DEVoE, R. D. Automated analyses of circadian rhythm activity of small arthropods. Behavior Research Methods \& Instrumentation, 1975, 7, 339-347.

Davis, J. M. (Duke Univ., Durham, N.C. 27706). A timing light for use with super-8 film cartridges. Behavior Research Methods \& Instrumentation. 1975, 7, 389-390.

Goldstein, M. L. (Indiana Univ., Kokomo, Ind. 46901). A simple circuit for administering electric shock to rats. Bulletin of the Psychonomic Society, 1975. 6. 105.

Goldstein, M. L. (Indiana Univ., Kokomo, Ind., 46901). An apparatus for the study of classical fear conditioning. Bulletin of the Psychonomic Society, 1975, 6. 106.

Hord, D. (Nav. Hith. Rsch. Ctr., San Diego, Calif. 92152). Common mode rejection techniques in conjugate eye movement recording during sleep. Psychophysiology, 1975, 12, 354-355.

Kimmel, H. D. (Univ. of South Florida, Tampa, Fla. 33620). RAY, R. L., \& KING, J. A television technique for quantifying conditioned and unconditioned responses of planarians. Behavior Research Methods \& Instrumentation. 1975, 7. 353-356.

Martinez, J. M., II, \& Sturr, J. F. A technique to verify a range of adapting luminances in which rods contribute to thresholds determined with a short wavelength test stimulus. Vision Research. 1975, 15, 861-863.

Modaresi, H. A. (Univ. of California, Riverside, Calif. 92502), Coe, W. V., \& Glendenning, B. J. An efficient one- and two-way avoidance apparatus capable of producing identical one- and two-way avoidance performance. Behavior Research Methods \& Instrumentation. 1975, 7, 348-350.

Muller, P. G. (Utah State Univ., Logan, Utah 84322), \& Cheney, C. D. The automatic recording of aggression in pigeons: A comparison of two methods with live targets. Behavior Research Methods \& Instrumentation, 1975, 7, 357-360.

Nash, R. F. (Marquette Univ., Milwaukee, Wis. 53233), \& Gallup, G. G., JR. Effect of different parameters of shock on tonic immobility. Behavior Research Methods \& Instrumentation, 1975, 7. 361-364.

Petrijohn, D. (M.I.T., Cambridge. Mass. 02139). Electronic windows. Behavior Research Methods \& Instrumentation, 1975. 7. $351-352$.

Wolach, A. H. (Illinois Inst. of Tech., Chicago, Ill. 60616), Roccaforte, P., \& Breuning, S. E. Converting an electronic calculator into a counter. Behavior Research Methods \& Instrumentation, 1975, 7, 365-367.

\section{HUMAN EXPERIMENTAL PSYCHOLOGY}

\section{HUMAN DEVELOPMENTAL CHANGES}

Arabie, P. (Elliott Hall. Univ. of Minnesota, Minneapolis, Minn. 55455), Kosslyn, S. M., \& Nelson, K. E. A multidimensional scaling study of visual memory of 5-year olds and adults. Journal of Experimental Child Psychology, 1975, 19, 327-345.

Ashrord, D. C.. \& Baumeister, A. A. (Univ. of Alabama, University. Ala. 35486). Cue selection in verbal discrimination learning of retarded subjects. Journal of Experimental Child Psychology, 1975. 19, 308-326.

BernhardT. A. J. (Washburn Univ., Topeka, Kans. 66621), \& FOREHAND, R. The effects of labeled and unlabeled praise upon lower and middle class children. Journal of Experimental Child Psychology, 1975, 19. 536-543.

Bloom, K. (Dalhousie Univ., Halifax, N.S., Canada), \& Esposito, A. Social conditioning and its proper control procedures. Journal of Experimental Child Psychology, 1975, 19. 209-222.

Bornstein, M. H. (Yale Univ., New Haven, Conn. 06520). Qualities of color vision in infancy. Journal of Experimental Child Psychology, 1975, 19, 401-419.

Brewer, W. F. (Psychol. Bldg., Univ. of Illinois, Champaign, Ill. 61820), \& StONE, J. B. Acquisition of spatial antonym 
pairs. Journal of Experimental Child Psychology, 1975, 19, 299-307.

Brown, A. L. (Children's Rsch. Ctr., 51 Gerty Dr., Champaign, Ill. 61820). Progressive elaboration and memory for order in children. Journal of Experimental Child Psychology, 1975, 19, 383-400.

CASler, L. (SUNY, Geneseo, N.Y. 14454). Supplementary auditory and vestibular stimulation: Effects on institutionalized infants. Journal of Experimental Child Psychology, 1975, 19, $456-463$.

CHI, M. T. H., \& KLAHR, D. Span and rate of apprehension in children and adults. Journal of Experimental Child Psychology, 1975, 19, 434-439.

Cramer, P. (Williams Coll., Williamstown, Mass. 01267). Learning pictures and words: The role of implicit verbal labeling. Journal of Experimental Child Psychology, 1975, 19, 489-501.

Cuvo, A. J. (Rehab. Inst., Southern Illinois Univ., Carbondale, Ill. 62901). Developmental differences in rehearsal and free recall. Journal of Experimental Child Psychology, 1975, 19, 265-278.

Davies, A. D. M. (Univ. of Liverpool, Liverpool, England), \& Davies, D. R. The effects of noise and time of day upon age differences in performance at two checking tasks. Ergonomics, 1975, 18, 321-336.

Denney, D. R. (Univ. of Kansas, Lawrence, Kans 66045). The effects of exemplary and cognitive models and selfrehearsal on children's interrogative strategies. Journal of Experimental Child Psychology, 1975, 19, 476-488.

Farnham-Diggory, S., \& Gregg, L. W. (Carnegie-Mellon Univ., Pittsburgh, Pa. 15213). Short-term memory function in young readers. Journal of Experimental Child Psychology, 1975, 19, 279-298.

DodD, B. (MRC Devel. Psychol. Unit, Drayton House, Gordon St., London W.C.1, England). Children's understanding of their own phonological forms. Quarterly Journal of Experimental Psychology, 1975, 27, 165-172.

Eimas, P. D. (Brown Univ., Providence, R.I. 02912). Distinctive feature codes in the short-term memory of children. Journal of Experimental Child Psychology, 1975, 19, 241-251.

Ford, W. (Ontario Inst. for Studies in Ed., 252 Bloor St. W., Toronto 181. Ont., Canada), \& Olson, D. The elaboration of the noun phrase in children's description of objects. Journal of Experimental Child Psychology, 1975, 19, 371-382.

HaRris, R. J. (Anderson Hall, Kansas State Univ., Manhatten, Kans. 66506). Children's comprehension of complex sentences. Journal of Experimental Child Psychology, 1975, 19, 420-433.

Hermelin, B. (MRC Devel. Psychol. Unit, Drayton House, Gordon St.. London W.C.1, England), \& O'ConnoR, N. Location and distance estimates by blind and sighted children. Quarterly Journal of Experimental Psychology, 1975, 27, 295-301.

Hoving, K. L. (Kent State Univ., Kent, Ohio 44242), Konick, D. S., \& WALlace, J. Memory storage and retrieval within and across modalities in children. Journal of Experimental Child Psychology, 1975, 19, 440-447.

Johansson, B. S. (Uppsala Univ., Uppsala, Sweden), \& Suölın, B. Preschool children's understanding of the coordinators "and" and "or." Journal of Experimental Child Psychology, 1975, 19. 233-240.

KrupsKi, A. (Grad. Sch. of Ed., UCLA, 405 Hilgard Ave., Los Angeles, Calif. 90024). Heart rate changes during a fixed reaction time task in normal and retarded adult males. Psychophysiology, 1975, 12, 262-267.

Leonard, L. B. (Memphis State Univ., Memphis, Tenn. 38152). The role of nonlinguistic stimuli and semantic relations in children's acquisition of grammatical utterances. Journal of Experimental Child Psychology, 1975, 19, 346-357.

Maratsos, M. P. (Inst. of Child Devel., Univ. of Minnesota. Minneapolis, Minn. 55455), \& ABramovitch, R. How children understand full, truncated, and anomalous passives. Journal of Verbal Learning and Verbal Behavior, 1975, 14, 145-157.
Matsuda, F. (c/o Prof. M. Matsuda, Chiba Univ., Chiba, Japan). Effects of space and velocity on time estimation in children and adults. Psychological Research, 1974, 37, 107-123.

Milla R, W. S. (Turnbull Bldg., Univ. of Strathclyde, Glasgow G1 1RD, Scotland). Visual attention to contingent and noncontingent stimulation in six- and nine-month-old infants. Psychological Research, 1975, 37, 309-319.

Murphy, M. D., \& Brown, A. L. (Children's Rsch. Ctr., 51 Gerty Dr., Champaign, Ill. 61820). Incidental learning in preschool children as a function of level of cognitive analysis. Journal of Experimental Child Psychology, 1975, 19, 509-523.

Oром, R. D. (134 Wesley Hall, Vanderbilt Univ., Nashville, Tenn. 37240), \& LEMond, C. M. The recall of relevant and incidental dimensional values as a function of perceptual salience, cognitive set, and age. Journal of Experimental Child Psychology, 1975, 19, 524-535.

Rybash, J. M., Roodin, P. A. (SUNY, Oswego, N.Y. 13126), \& Sullivan, L. F. The effects of a memory aid on three types of conservation judgments. Journal of Experimental Child Psychology, 1975, 19, 358-370.

Scarboro, M. E., \& Forehand, R. (Univ. of Georgia, Athens, $\mathrm{Ga}$. 30602). Effects of two types of response-contingent time-out on compliance and oppositional behavior of children. Journal of Experimental Child Psychology, 1975, 19, 252-264.

Schaller, M. J. (Univ. of Wisconsin, Madison, Wis., 53706). Chromatic vision in human infants: Conditioned operant fixation to "hues" of varying intensity. Bulletin of the Psychonomic Society, 1975, 6, 39-42.

Steinberg, E. R. (Univ. of Illinois, Champaign, Ill. 61820), \& ANDERSON, R. C. Hierarchical semantic organization in 6-yearolds. Journal of Experimental Child Psychology, 1975, 19, 544-553.

Vellutino, F. R. (SUNY, \& Albany Med. Coll., 1400 Washington Ave., Albany, N.Y. 12222), Steger, J. A., DeSetro, L., \& Phillips, F. Immediate and delayed recognition of visual stimuli in poor and normal readers. Journal of Experimental Child Psychology, 1975, 19, 223-232.

Williams, K. G. (Coll. of St. Teresa, Winona, Minn. 55987), \& Goulet, L. R. The effects of cueing and constraint instructions on children's free recall performance. Journal of Experimental Child Psychology, 1975, 19, 464-475.

Yussen, S. R. (Univ. of Wisconsin, 1025 W. Johnson St., Madison, Wis. 53706), \& LEVY, V. M., JR. Developmental changes in predicting one's own span of short-term memory. Journal of Experimental Child Psychology, 1975, 19, 502-508.

\section{PERCEPTUAL-AND SENSORY PROCESSES}

Gardner, H. (Psychol. Serv., Boston VA Hosp., $150 \mathrm{~S}$. Huntington Ave., Boston, Mass. 02130), \& ZuRIF, E. Bee but not be: Oral reading of single words in aphasia and alexia. Neuropsychologia, 1975, 13, 181-190.

\section{General}

MACKAY, D. M. (Dept. of Communication, Univ. of Keele, Keele, Staffs., England), \& MACKAY, V. Dichoptic induction of McCollough-type effects. Quarterly Journal of Experimental Psychology, 1975, 27, 225-233.

\section{Intersensory Comparisons}

BosshardT, H.-G. (Psychologisches Inst. der Ruhr-Universität Bochum, Postfach 2148, Germany). The influence of visual and auditory images on the recall of items of visual and auditory presentation mode. Psychological Research, 1975. 37, 211-227.

Casler, L. (SUNY, Geneseo, N.Y. 14454). Supplementary auditory and vestibular stimulation: Effects on institutionalized infants. Journal of Experimental Child Psychology, 1975. 19. $456-463$

Choe, C. S. (Univ. of Kansas, Lawrence, Kans. 66045), Welch. R. B., Gilford, R. M., \& Juola, J. F. The 
"icntriloquist effect": Visual dominance or response bias" Perception \& Psychophysics. 1975. 18. 55-60.

Нiтch, G. (Med. Rsch. Council. Applied Psychol. Unit. Cambridge. England), \& Morton. J. The unimportance of explicit spatial information in serial recall of visually presented lists. Quarterly Joumal of Experimental Psychology. $1975,27,161-164$.

\section{Illusions}

Girgus. J. S. (City Coll. of CUNY, 138th St. \& Convent Ave. New York. N.Y. 10031), \& Coren, S. Depth cues and constancy scaling in the horizontal-vertical illusion: The bisection error. Canadian Journal of Psychology, 1975, 29. 59-65.

Lehmкuhle, S. W., \& Fox. R. (Vanderbilt Univ., Nashville, Tenn. 37240). Effect of binocular rivalry suppression on the motion aftereffect. Vision Research, 1975, 15, 855-859.

Oyama, T. (Chiba Univ.. Yayiocho, Chiba 280, Japan). Determinants of the Zöllner illusion. Psychological Research, 1975, 37. 261-280.

Sigel, C., \& Nachmias, J. (Univ. of Pennsylvania, Philadelphia. $\mathrm{Pa}$. 19174). A re-evaluation of curvature-specific chromatic aftereffects. Vision Research, 1975. 15. 829-836.

Psichophysics

BAIRD, J. C. (Dartmouth Coll., Hanover. N.H. 03755), \& Noma. E. Psychophysical study of numbers. I. Generation of numerical responses. .Psychological Research, 1975. 37. 281-297.

Cross. D. V. (SUNY. Stony Brook. N.Y. 11794), Tursky, B. d LODGE. M. The role of regression and range effects in determination of the power function for electric shock. Perception \& Psychophysics, 1975, 18, 9-14.

Getty. D. J. (Brown Univ.. Providence. R.I. 02912). Discrimination of short temporal intervals: A comparison of two models. Perce'ption \& Psychophysics, 1975, 18, 1-8.

Martinez. J. M.. II (Syracuse Univ.. Skytop Labs.. M-15 Lambreth Lane. Syracuse, N.Y. 13210), \& STURR, J. F. A technique to verify a range of adapting luminances in which rods contribute to thresholds determined with a short wavelength test stimulus. Vision Research. 1975, 15, 861-863.

Tyler. C. W. (Bell Labs., 2D-504. 600 Mountain Ave. Murray Hill. N.J. 07974). Analysis of visual modulation sensitivity: Two components in flicker perception. Vision Research. 1975, 15, 843-848.

WagenaAR. W. A. (Inst. for Perception TNO. Kampweg 5 , Soesterberg. The Netherlands). Stevens vs Fechner: A plea for dismissal of the case. Acta Psychologica, 1975. 39. 225-235.

\section{Signal Detection}

Choе. C. S. (Univ. of Kansas, Lawrence. Kans. 66045), Welch, R. B., Gilford, R. M., \& Juola, J. F. The "ventriloquist effect": Visual dominance or response bias? Perception \& Psychophysics, 1975, 18. 55-60.

Navon, D. (Univ, of Haifa, Haifa 31999. Israel). A simple method for latency analysis in signal detection tasks. Perception \& Psychophysics, 1975, 18, 61-64.

Shakhar, G. B. (Hebrew Univ., Jerusalem, Israel), Lieblich, I., $\&$ Kugelmass, S. Detection of information and GSR habituation: An attempt to derive detection efficiency from two habituation curves. Psychophysiology, 1975, 12. 283-288.

\section{Vision}

Logan, G. D. (Queen's Univ., Kingston, Ont., Canada). On the independence of naming and locating masked targets in visual search. Canadian Journal of Psychology, 1975, 29, 51-58.

Purcell, D. G. (Oakland Univ.. Rochester. Mich. 48063), \& STEWART, A. L. A comparison of white and black targets under conditions of masking by a patterned stimulus. Bulletin of the Psychonomic Society, 1975, 6. 13-15.
Visual Se'nsitivity

Budohoska, W. (Dept. of Neurophysiol.. Nencki Inst. of Exptl. Biol., Warsaw, Poland), \& Celinski. M. Interactions between two simple visual patterns. Acta Neurobiologiae Experimentalis. 1975, 35, 125-137.

Forrest, D. W. (Trinity Coll.. Dublin, Ireland). Von Senden, Mesmer. and recovery of sight in the blind. American Journal of Psychology. 1974, 87, 719-722.

GotTwald, R. L. (Indiana Univ., South Bend. Ind. 46615), \& GARNER, W. R. Filtering and condensation tasks with integral and separable dimensions. Perception \& Psychophysics, 1975. 18. $26-28$

MaCKAY. D. M. (Dept. of Communication, Univ. of Keele, Keele. Staffs., England), \& MACKAY, V. Dichoptic induction of McCollough-type effects. Quarterly Journal of Experimental Psychology, 1975, 27. 225-233.

Maddess. R. J. (Univ. of Victoria, Victoria, B.C., Canada). Reaction time to hemiretinal stimulation. Neuropsychologia. 1975. 13. 213-218.

Thоmas. E. A. C. (Stanford Univ.. Stanford. Calif. 94305). $\&$ CANTOR. N. E. On the duality of simultaneous time and size perception. Perception \& Psychophysics, 1975, 18, 44-48.

\section{Spatial Vision}

Ashford, D. C., \& Baumeister, A. A. (Univ. of Alabama, University. Ala. 35486). Cue selection in verbal discrimination learning of retarded subjects. Journal of Experimental Child Psichology. 1975. 19. 308-326.

Bornstein. M. H. (Yale Univ., New Haven, Conn. 06520). Spectral sensitivity of the modulation-sensitive mechanism of vision: Effects of field size and retinal locus. Vision Research. 1975, 15, 865-869.

Chi. M. T. H., \& Klahr, D. (Carnegie-Mellon Univ.. Pittsburgh. Pa. 15213). Span and rate of apprehension in children and adults. Journal of Experimental Child Psychology. $1975,19,434-439$.

Coren. S. (Univ. of British Columbia, Vancouver, Canada), \& THEODOR, L. H. Subjective contour: The inadequacy of brightness contrast as an explanation. Bulletin of the Psychonomic Society, 1975. 6. 87-89.

Davis, J. M. (Duke Univ., Durham, N.C. 27706). A timing light for use with super-8 film cartridges. Behavior Research Methods \& Instrumentation, 1975, 7, 389-390.

Estes, W. K. (Rockefeller Univ., New York, N.Y. 10021). The locus of inferential and perceptual processes in letter identitication. Journal of Experimental Psychology: General, 1975, 104. 122-145.

Fox. R. (Vanderbilt Univ.. Nashville, Tenn. 37240), Todd, S., \& Bettinger, L. A. Optokinetic nystagmus as an objective indicator of binocular rivalry. Vision Research, 1975, 15. 849-853.

Hermelin, B. (MRC Devel. Psychol. Unit, Drayton House. Gordon St.. London W.C.1. England), \& O'ConnoR, N Location and distance estimates by blind and sighted children. Quarterly Joumal of Experimental Psychology, 1975, 27. 295-301.

Hock, H. S. (Florida Atlantic Univ., Boca Raton, Fla. 33432). \& Ross, K. The effect of familiarity on rotational transformation. Perception \& Psychophysics, 1975, 18, 15-20.

Krebs. W. (Inst. for Neurobiologie, KFA, 517 Jülich, Germany). HelRich, C. S., \& WulfF, V. J. The role of restricted extracellular compartments in vision. Vision Research, 1975. 15. 767.770 .

Lehmкuhle, S. W.. \& Fox, R. (Vanderbilt Univ., Nashville, Tenn. 37240). Effect of binocular rivalry suppression on the motion aftereffect. Vision Research, 1975, 15, 855-859.

Martinez, J. M.. II. (Syracuse Univ., Skytop Labs., M-15 Lambreth Lane, Syracuse, N.Y. 13210), \& STURR, J. F. A technique to verify a range of adapting luminances in which 
rods contribute to thresholds determined with a short wavelength test stimulus. Vision Research, 1975, 15, 861-863.

Mason, M. (Univ. of Connecticut. Storrs, Conn. 06268). Reading ability and letter search time: Effects of orthographic structure detined by single-letter positional frequency. Journal of Experimental Psychology: General, 1975, 104, 146-166.

Matsuda, F. (c/o Prof. M. Matsuda, Chiba Univ., Chiba, Japan). Effects of space and velocity on time estimation in children and adults. Psychological Research, 1974, 37, 107-123.

Munsinger, H. (Univ. of California, San Diego, La Jolla, Calif. 92().37). Most California college women already know that the surface of still water is always horizontal. American Journal of Psichology, 1974, 87, 717.718.

RUNESON. S. (Univ. of Uppsala, S:t Larsgatan 2, Uppsala S-752 20, Sweden). Constant velocity-not perceived as such. Psychological Research. 1974, 37, 3-23.

Tyler, C. W. (Bell Labs., 2D-504, 600 Mountain Ave., Murray Hill, N.J. 07974). Analysis of visual modulation sensitivity: Two components in flicker perception. Vision Re'search, 1975, 15. 843-848.

Vellutino, F. R. (SUNY. Albany, \& Albany Med. Coll., 1400 Washington Ave.. Albany, N.Y. 12222), STEGER, J. A., DeSetro. L.. \& Phillips, F. Immediate and delayed recognition of visual stimuli in poor and normal readers. Journal of Experimentul Child Psychology, 1975, 19, 223-232.

Wallach, H. (Swarthmore Coll., Swarthmore. Pa. 19081), \& BARTON, W. Adaptation to optically produced curvature of frontal planes. Perception \& Psychophysics, 1975, 18, 21-25.

White. K. G. (Victoria Univ., Wellington, New Zealand), \& Silver, A. B. Curchral hemispheres serve as two channels for visual intormation processing. Bulletin of the Psychonomic Society. 1975. 6. 51-52.

Wilton, R. N. (Univ. of Dundee, Dundee, Scotland), \& File, P. E. Knowledge of spatial relations: A preliminary investigation. Quurterly Journal of Experimental Psychology, $1975.27,251.257$

\section{Color Vision}

Bornstein, M. H. (Yale Univ., New Haven, Conn. 06520). Qualities of color vision in infancy. Journal of Experimental Child Psychology, 1975, 19, 401-419.

Budoнoska, W. (Dept. of Neurophysiol., Nencki Inst. of Exptl. Biol.. Warsaw, Poland), Grabowska, A., \& JABLONOWSKA. K. Interaction between two letters in visual perception. Acta Neurobiologiae Experimentalis, 1975, 35, $115-123$.

Flowers, J. H. (Univ. of Nebraska, Lincoln, Nebr. 68508). "Scnsory" interference in a word-color matching task. Perception \& Psychophysics, 1975, 18, 37-43.

Purcell, D. G. (Oakland Univ., Rochester, Mich. 48063), \& STEWART, A. L. A comparison of white and black targets under conditions of masking by a patterned stimulus. Bulletin of the Psychonomic Society, 1975, 6, 13-15.

Schaller, M. J. (Univ. of Wisconsin, Madison, Wis. 53706). Chromatic vision in human infants: Conditioned operant fixation to "hues" of varying intensity. Bulletin of the Psychonomic Society, 1975, 6, 39-42.

Sigel, C., \& Nachmias, J. (Univ. of Pennsylvania, Philadelphia, Philadelphia, $\mathrm{Pa}$. 19174). A re-evaluation of curvature-specific chromatic aftereffects. Vision Research, 1975, 15, 829-836.

\section{Eye Movements}

Bertera, J. H. (Dept. of Psychiat., \& Behav. Sci., Univ. of Oklahoma Hith. Sci. Ctr., Oklahoma City, Okla. 73190), Callan, J. R., Parsons, O. A., \& Pishkin, V. Lateral stimulus-Response compatibility effects in the oculomotor system. Acta Psychologica, 1975, 39, 175-181.

Goodenough, D. R. (Div. of Psychol. Studies, Ed. Testing Serv., Princeton, N.J. 08540), Witkin, H. A., Koulack, D., \& Conen, H. The effects of stress films on dream affect and on respiration and eye-movement activity during rapid-eyemovement sleep. Psychophysiology, 1975, 12. 313-320.
Hord, D. (Nav. Hlth. Rsch. Ctr., San Diego, Calif. 92152). Common mode rejection techniques in conjugate eye movement recording during sleep. Psychophysiology, 1975, 12, 354-355.

Millar, W. S. (Turnbull Bldg., Univ. of Strathclyde, Glasgow G1 1RD, Scotland). Visual attention to contingent and non-contingent stimulation in six- and nine-month-old infants. Psychological Research, 1975, 37, 309-319.

\section{Audition}

Davies, A. D. M. (Univ. of Liverpool, Liverpool, England), \& Davies, D. R. The effects of noise and time of day upon age differences in performance at two checking tasks. Ergonomics, 1975, 18. 321-336.

Long, J. (M.R.C., Applied Psychol. Unit, Chaucer Rd. Cambridge, England). Effects of randomly delayed visual and auditory feedback on keying performance. Ergonomics, $1975,18,337-347$

\section{Auditory Discrimination}

Efron, R. (Neurophysiol.-Biophysics Rsch. Labs., VA Hosp., 150 Muir Rd., Martinez, Calif. 94553), \& Yund, E. W. Dichotic competition of simultaneous tone bursts of different frequency-III. The effect of stimulus parameters on suppression and ear dominance functions. Neuropsychologia, $1975,13,151-161$.

Getry, D. J. (Brown Univ., Providence, R.I. 02912). Discrimination of short temporal intervals: A comparison of two models. Perception \& Psychophysics, 1975, 18, 1-8.

Provins, K. A. (Australian National Univ., Canberra, A.C.T., Australia), \& JeEves, M. A. Hemisphere differences in response time to simple auditory stimuli. Neuropsychologia. 1975, 13, 207-211.

Witcher, E. S. (Middlesex House, Univ. of Massachusetts, Amherst, Mass. 01002), \& AYres, J. J. B. Effect of removing background white noise during CS presentation on conditioning in the truly random control procedure. Bulletin of the Psychonomic Society, 1975, 6, 25-27.

Yund, E. W. (Neurophysiol.-Biophysics, Rsch. Labs., VA Hosp., 150 Muir Rd., Martinez, Calif. 94553), \& Efron, R. Dichotic competition of simultaneous tone bursts of different frequency-II. Suppression and ear dominance functions. Neuropsychologia, 1975, 13, 137-150.

\section{Speech Discrimination}

Dodd, B. (MRC Devel. Psychol. Unit, Drayton House, Gordon St., London W.C.1, England). Children's understanding of their own phonological forms. Quarterly Journal of Experimental Psychology, 1975, 27, 165-172.

LACKNER, J. R. (M.I.T., Cambridge, Mass. 02139), \& Goldstein, L. M. The psychological representation of speech sounds. Quarterly Journal of Experimental Psychology, 1975, 27, 173-185.

MARCER, D. (Univ. of Southampton, Highfield, Southampton SQ9 5NH, England). The acoustic similarity effect. Acta Psychologica, 1975, 39, 237-239.

\section{Other Senses}

Hermelin, B. (MRC Devel. Psychol. Unit, Drayton House. Gordon St., London W.C.1, England), \& O'Connor, N. Location and distance estimates by blind and sighted children. Quarterly Journal of Experimental Psychology. 1975, 27, 295-301.

\section{Chemical}

Jones, B. P. (Psychol. Serv., Boston VA Hosp., Boston. Mass. 02130), Moskowitz, H. R., \& Butters, N. Olfactory discrimination in alcoholic Korsakoff patients. Neuropsychologia, 1.75, 13, 173-179.

Klitzner, M. D. (Univ. of California, San Diego, La Jolla. Calif. 92037). Hedonic integration: Test of a linear model. Perception \& Psychophysics, 1975, 18, 49-54. 
YAMAZAKI, K. (Dept. of Neuropsychiat.. Fujita Gakuen Univ.. 1.98 Kutukake. Toyoake. Aichi 470-11. Japan). TAJimi, T., OKudA, K., \& NiImI, Y. Skin potential activity in rats. cats. and primates (including man): A phylogenetic point of view. Journal of Comparative and Physiological Psychology. 1975, 89, 364-370.

\section{Skin Sense's}

Murray, D. J. (Queen's Univ.. Kingston. Ont.. Canada). W ARD, R.. \& HockLEY, W. E. Tactile short-term memory in relation to the two-point threshold. Quarterly Journal of Experimental Psychology, 1975. 27. 303-312.

Roland, P. E. (Neurol. Dept. N 2082. Rigshospitalet. Blegdansvej 9. 2100 0. Copenhagen. Denmark). Some principles and new methods of tactile stimulation. Behavior Research Methods \& Instrumentation, 1975, 7. 333-338.

Schwartz, A. S. (Div. of Neurobiol.. Barrow Neurol. Inst. of St. Joseph's Hosp. \& Med. Ctr.. Phoenix. Ariz. 85013), Perey, A. J., \& Azulay. A. Further analysis of active and passive touch in pattern discrimination. Bulletin of the Psychonomic Society, 1975. 6. 7-9.

Shakhar, G. B. (Hebrew Univ., Jerusalem. Israel). Lieblich, I., \& Kugelmass, S. Detection of information and GSR habituation: An attempt to derive detection efficiency from two habituation curves. Psychophysiology, 1975, 12. 283-288.

\section{PERFORMANCE}

Psychomotor Tasks

Bertera. J. H. (Dept. of Psychiat. \& Behav. Sci.. Univ. of Oklahoma Hlth. Sci.. Ctr.. Oklahoma City. Okla. 73190), Callan, J. R., Parsons. O. A.. \& Pishinin. V. Lateral stimulus-Response compatibility effects in the oculomotor system. Acta Psychologica. 1975. 39. 175-181.

Davies, A. D. M. (Univ. of Liverpool. Liverpool. England), \& Davies, D. R. The effects of noise and time of day upon age differences in performance at two checking tasks. Ergonomics. 1975, 18. 321-336.

Demas, R. (Stantord Univ.. Stanford. Calif. 94305). \& Morgan. A. EEG asymmetry as a function of occupation, task, and task difficulty. Neuropsychologia, 1975, 13. 219-228.

ERTEL. S. (Institut für Psychologie der Universität Göttingen, Nikolausberger Weg 37, Göttingen, Germany), \& BloEmer, W.-D. Affirmation and negation as constructive action. Psychological Research, 1975, 37. 335-342.

KIRBY, N. H. (Univ. of Adelaide, Adelaide. Australia). Sequential effects in an eight choice serial reaction time task. Actu Psychologica, 1975, 39, 205-216.

Long, J. (M.R.C.. Applied Psychol. Unit, 15 Chaucer Rd., Cambridge, England). Effects of randomly delayed visual and auditory feedback on keýing performance. Ergonomics, 1975. 18. $337-347$.

\section{Reaction Time}

Burrows. D. (SUNY, Brockport, N.Y. 14420), \& OKADA, R. Memory retrieval from long and short lists. Science, 1975, 88, 1031-1033.

DRURY, C. G. (Dept. of Ind. Eng., SUNY, Buffalo, N.Y. 14214), \& Corlett, E. N. Control of performance in a multielement repetitive task. Ergonomics, 1975, 18, 279-298.

Flowers, J. H. (Univ. of Nebraska, Lincoln, Nebr. 68508). "Sensory" interference in a word-color matching task. Perception \& Psychophysics, 1975, 18, 37-43.

Hicks, R. E. (SUNY, 14 Washington Ave., Albany, N.Y. 12222). Asymmetry of bilateral transfer. American Journal of Psychology. 1974, 87, 667-674.

Hock. H. S. (Florida Atlantic Univ., Boca Raton, Fla. 33432), \& Ross, K. The effect of familiarity on rotational transformation. Perception \& Psychophysics, 1975, 18, 15-20.

Holender, D. (Lab. de Psychologie experimentale, 117, av. Ad. Buyl, 1050 Bruxelles, Belgium), \& Bertelson, P. Selective preparation and time uncertainty. Acta Psychologica, 1975, 39. 193.2(0).
Krupski. A. (Grad. Sch. of Ed., UCLA. 405 Hilgard Ave., Los Angeles. Calif. 90024). Heart rate changes during a tixed reaction time task in normal and retarded adult males. Psychophysiology. 1975, 12. 262-267.

Lyon. R. J. (Univ. of Guelph. Guelph, Ont., Canada NIG 2W1). Tong, J. E., Leigh. G., \& Clare, G. The influence of alcohol and tobacco on the components of choice reaction time. Journal of Studies on Alcohol. 1975 , 36. 587-596.

Maddess, R. J. (Univ. of Victoria, Victoria, B.C., Canada). Reaction time to hemiretinal stimulation. Neuropsychologia. 1975, 13, 213-218.

Мону, R. C. (Stanford Univ., Stanford, Calif. 94305), Wescourt, K. T., \& Atkinson, R. C. Search processes for associative structures in long-term memory. Journal of Experimental Psychology. 1975. 104. 103-121.

Scheerer-Neumann. G. (Psychologisches Inst. der RuhrUniversität. D.4630 Bochum. Postfach 2148, Germany). Formation and utilization of the visual and verbal codes of pictures and words. Psychological Research, 1974, 37. 81-106.

Briggs, G. G. (Dept. of Psychiat., Duke Univ. Med. Ctr. Durham. N.C. 27710). A comparison of attentional and control shift models of the performance of concurrent tasks. Acta Psychologica. 1975, 39, 183-191.

Graham. F. K. (Univ. Hosps.. Madison, Wis. 53706). The more or less startling effects of weak prestimulation. Psychophysiology. 1975, 12. 238-248.

Mason. M. (Univ. of Connecticut, Storrs, Conn. 06268). Reading ability and letter search time: Effects of orthographic structure defined by single-letter positional frequency. Journal of Experimental Psychology: General. 1975, 104, 146-166.

\section{Information Processing}

Knight, M. V., \& Parkinson, S. R. (Arizona State Univ., Tempe, Ariz. 85281). Stimulus set and response set: Influence of instructions on stimulus suffix effects in dichotic memory. Journal of Experimental Psychology: Human Learning and Memony, 1975, 104. 408-414.

Povel, D.-J. (Univ. of Nijmegen, Erasmuslaan 16, Nijmegen. The Netherlands). Evaluation of the vowel corrector as a speech training device for the deaf. Psychological Research. 1974 . 37. $71-80$.

Prinz. W. (Psychol. Inst. d. Ruhr-Univ. Bochum, D-4630, Postfach 2148, Germany) \& Scheerer-Neumann, G. Component processes in multiattribute stimulus classification. Psychological Research, 1974, 37, 25-50.

Shakhar, G. B. (Hebrew Univ., Jerusalem, Israel), Lieblich, I.. \& Kugelmass, S. Detection of information and GSR habituation: An attempt to derive detection efficiency from two habituation curves. Psychophysiology, 1975, 12, 283-288.

WARD, L. M. (Univ. of British Columbia, Vancouver, B.C., Canada V6T IW5). Heuristic use or information integration in the estimation of subjective likelihood? Bulletin of the Psychonomic Society, 1975, 6, 43-46.

\section{Sleep and Fatigue}

Berg, W. K., Jackson, J. C., \& Graham, F. K. (Univ. of Wis., Univ. Hosps., Madison, Wis. 53706). Tone intensity and rise-decay time effects on cardiac responses during sleep. Psychophysiology, 1975, 12, 254-261.

Levin, I. (Bar-llan Univ., Ramat Gan, Israel), \& GLaubMan, $H$. The effect of REM deprivation: Is it detrimental. beneficial. or neutral? Psychophysiology, 1975, 12, 349-353.

WeBB. W. B. (Univ. of Florida, Gainesville, Fla. 32601), \& AGNew, H. W., JR. Are we chronically sleep deprived? Bulletin of the Psychonomic Society, 1975, 6, 47-48. 


\section{HUMAN LEARNING} Conditioning

Edwards. J. S. (Linir. of Missouri, CB Annex, Rm. 100, Kansas (ity. Mo. (6411(1)). Edwards. D. DeA.. \& Lucas, J. Differential effects of communication on operant behavior in children. Bulletin of the Psychonomic Society, 1975, 6, 90-92.

Hare. R. D. (Univ. of British Columbia, Vancouver, Canada V(til IW5). \& Blevings, G. Conditioned orienting and defensive responses. Psychophysiology, 1975, 12, 289-297.

Millar, W. S. (Univ. of Strathclyde, Turnbull Bldg., Glasgow, Gi 1RD, Scotland). Visual attention to contingent and non-contingent stimulation in six- and nine-month-old infants. Psychological Research, 1975, 37, 309-319.

Weiss, T. (Dept. of Psychiat., Univ. of Pennsylvania, Philadelphia, Pa. 19174), \& ENGEl, B. T. Evaluation of an intra-cardiac limit of learned heart rate control. Psychophysiology, 1975, 12, 310-312.

Williams, W. C. (Univ. of Utah. Salt Lake City, Utah 84112). Classical skin conductance response conditioning: Effects of intermittent reinforcement and information about schedule contingencies. Journal of Experimental Psychology: Human Learning and Memory. 1975. 104. 501-509.

Witcher, E. S. (Middlesex House. Univ. of Massachusetts, Amherst. Mass. 01002), \& Ayres, J. J. B. Effect of removing background white noise during CS presentation on conditioning in the truly random control procedure. Bulletin of the Psychonomic Society, 1975. 6. 25-27.

\section{Discrimination Learning}

Ashford. D. C.. d Baumeister. A. A. (Univ. of Alabama, L'niversity. Ala. 35486). Cue selection in verbal discrimination karning of retarded subjects. Joumal of Experimental Child Psychology. 1975. 19. 308-326.

Brewer. W. F. (Psychol. Bldg.. Univ. of Illinois. Champaign. III. 61820). \& Stone, J. B. Acquisition of spatial antonym pairs. Journal of Experimental Child Psychology. 1975. 19. 299-307.

Leonard. L. B. (Memphis State Univ.. Memphis. Tenn. 38152). The role of nonlinguistic stimuli and semantic relations in children's acquisition of grammatical utterances. Journal of Experimental Child Psychology. 1975. 19. 346-357.

Richards. L. G. (L'nis. of Virginia, Charlottesville, Va. 22901), \& Platnick. D. M. On the influence of pretraining on recognition thresholds for English words. American Journal of Psychology'. 1974, 87, 579-592.

Richman, C. L. (Wake Forest Univ., Winston-Salem. N.C. 27109). Bidwell. L.. \& Hynson. K. The effeets of temporal factors on reversal and half-reversal shifts. American Journal of Psichology. 1974. 87. 683-692.

Scholtz. G. J. L.. ¿ Eleis. M. J. (Dalhousie Univ.. Halitax. N.S.. (anadal. Repeated exposure to objects and peers in a play setting. Journal of Experimental Child Psichology. 1975, 19. $448-455$.

Shefts. (C. A. JR. ll nis of Colorado. Boulder. Colo. 80302), \& Mitier. M. J. The effect of cue-criterion function form on multiple-cue probability learning. American Journal of Psychology. 1974, 87. 629-641.

\section{Verbal Learning}

L.rppman. L. G. (Western Washington State Coll., Bellingham, Wash. 98225). List onset and isolation in continuous serial kearning. American Journal of Psychology, 1974, 87, 693-698.

Lippman, L. G. (Western Washington State Coll. Bellingham, Wash. 98225). Item effects as indicators of subjective organization in serial learning. American Journal of Psychology, 1974. 87, 699-705.

WIISON. A. (Dept. of Psychiat., Faculty of Med., Univ. of Manitoha, 770 Bannatyne Ave., Winnipeg R3E OW3. Canada). The inference of covert hypotheses by verbal reports in concept-karning research. Quarterly. Journal of Experimental Psychology, 1975, 27, 31,3-322.
Paired-Associate Learming

Brown. A. L (Children's Rsch. Ctr., 51 Gerty Dr.. Champaign. III. o182()). Progressive elaboration and memory for order in children. Journal of Experimental Child Psychology, 1975. 19. 38.3 .4()() .

Cramer. P. (Williams Coll., Williamstown, Mass. (01267). Learning pictures and words: The role of implicit verbal labeling. Journal of Experimental Child Psychology. 1975. 19. 489-501.

Erickson, R. L. (Univ, of New Hampshire, Durham. N.H. 03824). Stimulus context effects, associative strength, and word frequency as determiners of free recall in pairedassociate learning. Canadian Journal of Psychology, 1975, 29. 4.3- $\overline{-}()$.

Morris, P. E. Univ. of Lancaster, Lancaster, England), \& Reid, R. L. The role of stimulus and pair imagery in pairedassociate learning. British Journal of Psychology, 1975. 66. 153-156.

Powell, G. D. (Univ. of Texas. Austin, Tex. 78712), Hamon. T. G., \& Young, R. K. Selective encoding interference in paired-associate learning. Joumal of Experimental Psychology: Human Learning and Memory, 1975, 104, 473-479.

D'Ydewalle, G. (Univ. of Leuven, B-3000 Leuven, Belgium). d EELEN. P. Repetition and recall of "right" and "wrong" responses in incidental and intentional learning. Journal of Experimental Psychology: Human Learning and Memory. $1975,104.429-441$.

\section{Reinforcement}

Cox, W. M. (Dept. of Med. Psychol., Univ. of Oregon Hith. Sci. Ctr., Portland, Oreg. 97201), Weitz, J. R., \& Lieberman. L. R. Shifts in magnitude of reward with humans in the "straightaway." Bulletin of the Psychonomic Society. 1975. 6. 1-3.

Scarboro, M. E. \& Forehand, R. (Univ. of Georgia, Athens. Ga. 306(2). Effects of two types of response-contingent time-out on compliance and oppositional behavior of children. Journal of Experimental Child Psychology, 1975, 19. 252-264.

Williams, W. C. (Univ. of Utah, Salt Lake City. Utah 84112). Classical skin conductance response conditioning: Effects of intermittent reinforcement and information about schedule contingencies. Journal of Experimental Psychology: Human Le'arming and Memory. 1975. 104. 501-509.

Yaroush, R. A. (Univ. of Denver, 2030 S. York, Denver. Colo. 80210). Sequential concept formation. hypothesis testing. and the PRE effect. Bulletin of the Psychonomic Societr. 1975. 6. 83-86.

\section{HUMAN MEMORY}

Arabie. P. (Elliott Hall. Univ. of Minnesota, Minneapolis. Minn. 55455). Kosslyn, S. M.. \& Nelson, K. E. A multidimensional scaling study of visual memory of 5-year olds and adults. Journal of Experimental Child Psychology. 1975. 19. 327-345.

Brown, A. L. (Children's Rsch. Ctr., 51 Gerty Dr.. Champaign. 111. 61820). Progressive elaboration and memory for order in children. Joumal of Experimental Child Psychology, 1975, 19. $38.3-400$.

Burrows. D. (SUNY. Brockport. N.Y. 14420). \& OKadA, R. Memory retrieval from long and short lists. Science. 1975. 188. $10,31-10,33$.

Carros. H. S. (Dept. of Communication Arts de Sci.. Queens (oll. Flushing. N.Y. 11367), d Kamerman. J. Lexical information processing during sentence comprehension. Journal of Verbal Le'arning and Verbal Behavior. 1975, 14, 170-179.

Dincan, C. P. (Northwestern Univ.. Evanston, Ill. 60201). Prodded retricval from a semantic category. Bulletin of the Psychonomic Society, 1975, 6. o1-62.

Frederiksen, C. H. (Univ. of California, Berkeley, Calit. 9472(3). Aequisiton of semantic intormation from discourse:

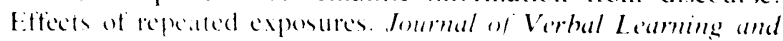
lind Behaw, 1975, 14. 158-16\%. 
Geis. M. F., d Winograd. E. (Emory Univ.. Atlanta. Ga. 30.322). Semantic encoding and judgments of background and situational frequency for homographs. Journal of Experimental Psychology: Human Learning and Memon. $19^{-5}$. 104. 385-392.

Geiselman, R. E. (Ohio Univ., Athens, Ohio 45701), \& RiEHLE, J. P. The fate of to-be-forgotten sentences in semantic positive forgetting. Bulletin of the Psychonomic Society. 19-5. 6. 19-21.

Gray. M. J. (Salem State Coll., 352 Lafayette St., Salem. Mass. 01970). Effects of shadowing on reading. Journal of Experimental Psychology: Human Learning and Memon. $1975,104,423-428$.

Knight. M. V.. \& Parkinson, S. R. (Arizona State Univ., Tempe, Ariz. 85281). Stimulus set and response set: Influence of instructions on stimulus suffix effects in dichotic memory. Journal of Experimental Psychology: Human Learning and Memon, 1975, 104. 408-414.

Lewin. I. (Bar-llan Univ., Ramat Gan, Israel), \& Glaubman, $\mathrm{H}$. The effect of REM deprivation: Is it deterimental, beneficial. or neutral? Psychophysiology, 1975, 12, 349-353.

Little, W. A. (Physics Dept., Stanford Univ., Stanford. Calif 94305). \& Shaw. G. L. A statistical theory of short and long term memory. Behavioral Biology, 1975, 14, 115-133.

Монs, R. C. (Stanford Univ., Stanford, Calif. 94305), Wescourt, K. T., \& Atkinson, R. C. Search processes for associative structures in long-term memory. Journal of Experimental Psychology: General, 1975, 104, 103-121.

MurPhy. M. D., \& Brown. A. L. (Children's Rsch. Ctr., 51 Gerty Dr., Champaign. Ill. 61820). Incidental learning in preschool children as a function of level of cognitive analysis. Journal of Experimental Child Psychology, 1975, 19. 509-523.

Peterson, R. G. \& McIntyre, C. W. (Univ. of Virginia, Charlottesville, Va. 22901). The influence of synonym substitution on integrated recognition memory. American Journal of Psychology, 1974. 87. 707-716.

Rowe. E. J. (Memorial Univ. of Newfoundland. St. John's. Ntld., Canada A1C 5S7), \& Rogers, T. B. Effects of concurrent auditory shadowing on free recall and recognition of pictures and words. Journal of Experimental Psychology: Human Learning and Memory, 1975, 104, 415-422.

RYBash. J. M., Roodin, P. A. (SUNY, Oswego, N.Y. 13126). d Sullivan. L. F. The effects of a memory aid on three types of conservation judgments. Joumal of Experimental Child Psichology. 1975, 19. 358-370.

Scheerer-Neumann. G. (Psychologisches Inst. der Ruhriniversität, D-4630 Bochum, Postfach 2148, Germany). Formation and utilization of the visual and verbal codes of pictures and words. Psychological Research. 1974. 37, 81-106.

Steinberg. E. R. (Univ. of Illinois. Champaign. Ill. 61820), d ANDerson, R. C. Hierarchical semantic organization in o-vear-olds. Journal of Experimental Child Psychology. 1975. 19. $544-553$.

Vellutino, F. R. (SUNY. \& Albany Med. Coll., 1400 Washington Are.. Albany, N.Y. 12222), Steger, J. A., DeSetto. L., \& Phillips, F. Immediate and delayed recognition of visual stimuli in poor and normal readers. Journal of Experimental Child Psychology, 1975, 19. 223-232.

\section{Long-Term Memory}

Hogan, R. M. (Rockefeller Univ., 66th \& York Ave., New York, N.Y. 10021). Influences of relevant and irrelevant vocalization in verbal recall. Journal of Experimental Psychology: Human Learning and Memory, 1975, 104, 466-472.

MACFY, W. H., \& Zechmeister, E. B. (Loyola Univ., Chicago, III. 60626). Test of the multiple-trace hypothesis: The effects of temporal separation and presentation modality. Journal of Experimental Psychology: Human Learning and Memory. 1975. 104. 459-465.
Oром. R. D. (134 Wesley Hall. Vanderbilt Univ.. Nashville. Tenn. 37240), \& Lemond, C. M. The recall of relevant and incidental dimensional values as a function of perceptual salience. cognitive set, and age. Journal of Experimental Child Psychology. 1975, 19, 524-535.

D'Ydew alle, G. (Univ. of Leuven, B3000 Leuven, Belgium), \& EELEN. P. Repetition and recall of "right" and "wrong" responses in incidental and intentional learning. Journal of Experimental Psychology: Human Learning and Memory, 1975. 104. $429-441$.

\section{Free Recall}

Albert, D. (Fachbereich Psychologie, Philipps-Universität, Marburg/Lahn, Germany), \& Schulz, U. A model for free recall of two lists: Individual recall sequences and the effect of list-2-dominance. Acta Psychologica, 1975, 39, 161-174.

Andre. T. (Iowa State Univ., Ames, Iowa 50010), Anderson, R. C.. \& W WTTs, G. H. Organizational strategy and retroactive inhibition in free recall. American Joumal of Psychology, 1974. 87. 609-628.

Barrett, T. R., Maier, W., Ekstrand, B. R. (Univ. of Colorado, Boulder. Colo. 80302), \& Pellegrino, J. W. Effects of experimenter-imposed organization on long-term forgetting. Journal of Experimental Psychology: Human Learning and Memon, 1975, 104, 480-490.

Birnbaum, I. M. (Sch. of Soc. Sci., Univ. of California, Irvine. Calif. 92664). Organization of numbers in free recall. Journal of Experimental Psychology: Human Learning and Memon' 1975, 104, 393-399.

Bosshardt, H.-G. (Psychologisches Institut der RuhrUniversität, D-4630 Bochum, Postfach 2148, Germany). The influence of visual and auditory images on the recall of items of visual and auditory presentation mode. Psychological Research. 1975, 37, 211-227.

Chapman, C., Pellegrino, J. W., \& Battig, W. F. (Univ. of Colorado, Boulder, Colo. 80302). Input order and grouping in free-recall learning and organization. American Journal of Psychology, 1974, 87, 565-577.

Cuvo, A. j. (Rehab. Inst., Southern Illinois Univ., Carbondale. Ill. 62901). Developmental differences in rehearsal and free recall. Journal of Experimental Child Psychology, 1975, 19, 265-278.

Darley, C. F., \& Glass, A. L. (Stanford Univ., Stanford, Calif. 94305). Effects of rehearsal and serial list position on recall. Journal of Experimental Psychology: Human Learning and Memory, 1975, 104, 453-458.

ENGElKamP, J. (Psychologisches Institut, Ruhr-Universität, D-4630 Bochum, Postfach 2148, Germany). The interaction of semantic features of transitive verbs and their objects. Psychological Research. 1975. 37, 299-308.

ERICKSON, R. L. (Univ. of New Hampshire, Durham, N.H. 03824). Stimulus context effects, associative strength, and word frequency as determiners of free recall in pairedassociate learning. Canadian Joumal of Psychology, 1975, 29. 43-50.

Hoving, K. L. (Kent State Univ., Kent, Ohio 44242), Konick. D. S., \& WALLACE, J. Memory storage and retrieval within and across modalities in children. Journal of Experimental Child Psychology, 1975, 19, 440-447.

Townsend, D. J. (Montclair State Coll., Upper Montclair, N.J. 07043), \& SALTz, E. The effects of stimulus frequency on subsequent recall of backward associates. Canadian Journal of Psychology, 1975, 29, 3-10.

Tulving, E. (Univ. of Toronto, Toronto, Canada M5S 1A1), $\&$ WISEMAN, S. Relation between recognition and recognition failure of recallable words. Bulletin of the Psychonomic Society, 1975, 6, 79-82.

Williams, K. G. (Coll. of St. Teresa, Winona, Minn. 55987), \& Goulet, L. R. The effects of cueing and constraint 
instructions on children's free recall performance. Journal of Exprerimentul Child Psychology, 1975, 19, 464-475.

\section{Short-Term Memory}

Bennett, R. W. (Univ. of Illinois at Chicago Circle, Chicago, III. 60680). Proactive interference in short-term memory: Fundamental forgetting processes. Journal of Verbal Learning and Verbal Behavior. 1975, 14, 123-144.

Bird, C. P. (Florida State Univ., Tallahassee, Fla. 32306), \& WEAVER. G. E. Interpolated task characteristics and interference in short-term memory. Bulletin of the Psychonomic Societl. 1975, 6, 93-95.

Drevenstedt, J. (Porter Hall, Ohio Univ., Athens, Ohio 45701) Random consonant grouping and effect on partial recall. Journal of Experimental Psychology: Human Learning and Memon. 1975, 104, 400-407.

Ermas, P. D. (Brown Univ., Providence, R.I. 02912) Distinctive feature codes in the short-term memory of children Journal of Experimental Child Psychology, 1975, 19, 241-251.

ERTEl. S. Institut für Psychologie der Universität Göttingen, Nikolatusberger Weg 37, D-3400 Göttingen, Germany), \& BiOEMER, W.-D. Affirmation and negation as constructive action. Psychological Research. 1975, 37. 335-342.

FARNhAM-Diggory, S., \& GREGG, L. W. (Carnegie-Mellon Univ.. Pittsburgh, Pa. 15213). Short-term memory function in young readers. Journal of Experimental Child Psychology, $1975,19,279-298$.

Hitch, G. (Med. Rsch. Council, Applied Psychol. Unit, (ambridge, England). \& Morton. J. The unimportance of explicit spatial information in serial recall of visually presented lists. Quarterly Journal of Experimental Psychology, 1975. 27. $.101-104$.

Holender, D. (Lab. de Psychologie experimentale, 117, av. Ad. Buyl, 1050 Bruxelles, Belgium), \& Bertelson, R. Selective preparation and time uncertainty. Acta Psychologica, 1975, 39. 193-203.

Kintsch, W. (Univ, of Colorado, Boulder, Colo. 80302), Kozminsky, E., Streby, W. J., McKoon, G., \& Keenan, J. M. Comprehension and recall of text as a function of content variables. Journal of Verbal Learning and Verbal Behavior, 1975, 14, 196-214.

Marcer, D. (Univ. of Southampton, Highfield, Southampton SQ9 $5 \mathrm{NH}$, England). The acoustic similarity effect. Acta Psychologica, 1975, 39, 237-239.

Marteniuk, R. G. (Univ. of Waterloo, Waterloo, Ont., Canada), \& Diewert, G. L. Decay and interference effects in motor short-term memory. Acta Psychologica, 1975, 39, 217-223.

McNicol, D. (Sch. of Psychol., Univ. of New South Wales. P.O. Box 1, Kensington, N.S.W., 2033, Australia). Fixed and random address models for storing order in short-term memory. Quarterly Journal of Experimental Psychology, 1975, 27, 273-288.

MurRay, D. J. (Queen's Univ., Kingston, Ont., Canada), WARD, R., \& HoCKLEY, W. E. Tactile short-term memory in relation to the two-point threshold. Quarterly Journal of Experimental Psychology, 1975, 27, 303-312.

Winsick, R. H. (Univ. of South Carolina, Columbia, S.C. 29208). Attribute-specific retroactive inhibition in Peterson and Peterson type short-term memory tasks. Bulletin of the Psychonomic Society, 1975, 6, 55-56.

Yussen, S. R. (Dept. of Ed. Psychol., Univ. of Wisconsin, 1025 W. Johnson St., Madison, Wis. 53706), \& LEVY, V. M., JR. Developmental changes in predicting one's own span of short-term memory. Journal of Experimental Child Psychology, 1975, 19, 502-508.

\section{Transfer}

Andre, T. (Iowa State Univ., Ames, Iowa 50010), Anderson, R. C., \& W ATTs, G. H. Organizational strategy and retroactive inhibition in free recall. American Journal of Psychology, 1974. 87. 609-628.
McNicol, D. (Sch. of Psychol.. Univ. of New South Wales, P.O. Box 1, Kensington, N.S.W. 2033, Australia). Fixed and random address models for storing order in short-term memory. Quarterly Journal of Experimental Psychology, $1975,27,273-288$.

Nicosia, G. J., \& Santa, J. L. (Rutgers Univ., Douglass Coll., New Brunswick, N.J. 08903). Words and the reproduction of nonsense things. Journal of Experimental Psychology: Human Learning and Memory, 1975, 104, 369-375.

Richardson, J. T. E. (Lab. of Exptl. Psychol., Univ. of Sussex, Brighton, BN1 9QG, England). Imagery, concreteness, and lexical complexity. Quarterly Journal of Experimental Psychology, 1975, 27, 211-223.

Richardson, J. T. E. (Lab. of Expt. Psychol., Univ. of Sussex, Brighton BN1 9QG, England). Concreteness and imageability. Quarterly Journal of Experimental Psychology, 1975, 27, 235-249.

Runouist, W. N. (Univ. of Alberta, Edmonton, Alta., Canada). Stimulus structure, discrimination, and interference. Journal of Experimental Psychology: Human Learning and Memory, 1975. 104. 491-500.

Underwood. G. (Univ. of Nottingham, Nottingham NG7 2RD, England). Perceptual distinctiveness and proactive interference in the primacy effect. Quarterly Journal of Experimental Psychology. 1975, 27, 289-294.

Watkins, O. C., (Univ. of Toronto, Toronto M5S 1A1. Ont.. Canada), \& Watkins, M. J. Buildup of proactive inhibition as a cue-overload effect. Journal of Experimental Psychology: Human Learning and Memory, 1975, 104 $442-452$.

Winnick, R. H. (Univ. of South Carolina, Columbia, S.C. 29208). Attribute-specific retroactive inhibition in Peterson and Peterson type short-term memory tasks. Bulletin of the Psychonomic Society, 1975, 6, 55-56.

Wiseman, S., \& NeIsser, U. (Cornell Univ., Ithaca, N.Y. 14850). Perceptual organization as a determinant of visual recognition memory. American Journal of Psychology, 1974. 87. 675-681.

\section{HUMAN THINKING}

Verbal Processes

BAIRD, J. C., (Darmouth Coll., Hanover, N.H. 03755), \& Noma, E. Psychophysical study of numbers. I. Generation of numerical responses. Psychological Research, 1975, 37, 281-297.

CaIRns, H. S. (Dept. of Communication Arts \& Sci., Queens Coll., Flushing, N.Y. 11367), \& Kamerman, J. Lexical information processing during sentence comprehension. Journal of Verbal Learning and Verbal Behavior, 1975, 14, 170-179.

Dickstein, L. S. (Wellesley Coll., Wellesley, Mass. 02181). Effects of instructions and premise order on errors in syllogistic reasoning. Journal of Experimental Psychology: Human Learning and Memory, 1975, 104, 376-384.

ENGELKAMP, J. (Psychologisches Institut, Ruhr-Universität, D-4630 Bochum, Postfach 2148, Germany). The interaction of semantic features of transitive verbs and their objects. Psychological Research, 1975, 37, 299-308.

Fillenbaum, S. (Univ. of North Carolina, Chapel Hill, N.C. 27574). If: Some uses. Psychological Research, 1975, 37. 245-260.

Ford, W. (Ontario Inst. for Studies in Ed., 252 Bloor St., W.. Toronto 181, Ont., Canada), \& OLson, D. The elaboration of the noun phrase in children's description of objects. Journal of Experimental Child Psychology, 1975, 19, 371-382.

Holyoak, K. J., \& Glass, A. L. (Stanford Univ., Stanford, Calif. 94305). The role of contradictions and counterexamples in the rejection of false sentences. Journal of Verbal Learning and Verbal Behavior, 1975, 14, 215-239.

Hupet, M. (Dept. of Exptl. Psychol., Univ. of Louvain, Louvain. Belgium), \& Le Bouedec, B. Definiteness and voice 
III the interpretation of active and passive sentences. Quarterly Journal of Experimental Psychology'. 1975, 27, 323-330.

Johansson. B. S. (Uppsala Univ.. Uppsala, Sweden), \& Sülin. B. Preschool children's understanding of the coordinators "and" and "or." Jourmal of Experimental Child Psichology, 19-5. 19, 233-240.

Maratsos. M. P.. (Inst. of Child Devel., Univ. of Minnesota. Minneapolis. Minn. 55455). \& AB Ramovitch, R. How children understand full. truncated, and anomalous passives. Journal of Verbal Learning and Verbal Behavior, 1975. 14, 145-157.

Shallice. T. (National Hosp., Queen Sq., London W.C.1, England), \& WARrington, E. K. Word recognition in a phonemic dyslexic patient. Quarterly Journal of Experimental Psychology, 1975. 27, 187-199.

Steinberg. E. R. (Univ. of Illinois. Champaign, Ill. 61820), d ANDERSON. R. C. Hierarchical semantic organization in 6-year-olds. Journal of Experimental Child Psychology. 1975. 19. $544-553$.

\section{Problem Solving}

Casella. D. Z. (Fordham Univ.. Bronx. N.Y. 10458), \& VAUGHTER. R. M. Comparison of paradigms in problem solving: Matching to sample, responding to similarity, and oddity. Bulletin of the Psychonomic Society, 1975, 6, 63-64.

DeNNEY, D. R. (Univ. of Kansas. Lawrence, Kans. 66045). The effects of exemplary and cognitive models and selfrehearsal on children's interrogative strategies. Journal of Experimental Child Psychology, 1975, 19. 476-488.

Kaiser, D. N.. \& Sandman. C. A. (Ohio State Univ.. Columbus. Ohio 43210). Physiological patterns accompanying complex problem solving during warning and nonwarning conditions. Journal of Comparative and Physiological Psuchology. 1975, 89. 357-363.

Lic, I. (National Taiwan Univ.. Taipei, Taiwan, Rep. of China). Sequential hypothesis-testing behavior. American Journal of Psychology. 1974, 87, 593-607.

Stratton. R. P. (Univ. of Kentucky, Lexington, Ky. 40506), JACobus. K. A., \& LeONARD., S. D. Solving anagrams as a function of word frequency, imagery and distribution of practice. Canadian Journal of Psychology, 1975, 29, 22.

W ARD. L. M. (Univ. of British Columbia, Vancouver, B.C. Canada V6T 1W5). Heuristic use or information integration in the estimation of subjective likelihood? Bulletin of the Psychonomic Society, 1975, 6, 43-46.

\section{Concepts}

Allan, L. G. (McMaster Univ.. Hamilton, Ont., Canada). The relationship between judgments of successiveness and judgments of order. Perception \& Psychophysics, 1975, 18. 29-36.

Barresi, J., Robbins, D. (Emory Univ.. Atlanta, Ga. 30322), \& Shain, K. Role of distinctive features in the abstraction of related concepts. Journal of Experimental Psychology: Human Learning and Memory, 1975, 104, 360-368.

Cotton, J. W. (Grad. Sch. of Ed.. Univ. of California, Santa Barbara, Calif. 92106). Effects of stimulus congruence on hypotheses held in a concept identification task. Psychological Research, 1975, 37, 229-243.

Homa, D. (Div. of Natl. Sci., New Coll., Sarasota, Fla. 33578), $\&$ Chambliss, D. The relative contributions of common and distinctive information on the abstraction from ill-defined categories. Journal of Experimental Psychology: Human Lecirning and Memory, 1975, 104, 351-359.

Kappauf, W. E. (Univ. of Illinois. Champaign, Ill. 61820), \& Bohrer, R. Observations on mixed binomials. American Journal of Psychology, 1974, 87, 643-665.

Peterson, R. G., \& McIntyre, C. W. (Univ. of Virginia, Charlottesville. Va. 22901). The influence of synonym substitution on integrated recognition memory. American Journal of Psychology, 1974, 87, 707-716.
Seggie, J. L. (Univ. of Newcastle, Newcastle, N.S.W. Australia). The empirical observation of the Piagetian concept of correlation. Canadian Journal of Psychology, 1975, 29. 32.

Wilson, A. (Dept. of Psychiat., Faculty of Med.. Univ. of Manitoba, 770 Bannatyne Ave., Winnipeg R3E OW3, Canada). The inference of covert hypotheses by verbal reports in concept-learning research. Quarterly Journal of Experimental Psychology, 1975, 27, 313-322.

Yaroush, R. A. (Univ. of Denver, 2030 S. York, Denver, Colo. 80210). Sequential concept formation, hypothesis testing, and the PRE effect. Bulletin of the Psychonomic Society. $1975,6,83-86$.

\section{SOCIAL PROCESSES}

Edwards, J. S. (Univ. of Missouri, CB Annex, Rm. 100 , Kansas City, Mo. 64110), Edwards, D. D., \& Lucas, J. Differential effects of communication on operant behavior in children. Bulletin of the Psychonomic Society, 1975, 6, 90-92.

Geen, R. G. (Univ. of Missouri, Columbia, Mo. 65201), \& Stonner, D. Primary associates to 20 verbs connoting violence. Behavior Research Methods \& Instrumentation, 1975, 7, 391-392.

Zanna. M. P. (Princeton Univ., Princeton, N.J. 08940), Sheras, P. L., Cooper, J., \& Shaw, C. Pygmalian and Galatea: The interactive effect of teacher and student expectancies. Journal of Experimental Social Psychology, 1975. 11. $279-287$.

\section{Attraction}

Benware, C.. \& Deci, E. L. (Univ. of Rochester, Rochester, N.Y. 14627). Attitude change as a function of the inducement for espousing a proattitudinal communication. Journal of Experimental Social Psychology, 1975, 11, 271-278.

Brickman, P. (Northwestern Univ., Evanston. Ill. 60201), MEYeR, P.. \& FREDd, S. Effects of varying exposure to another person with familiar or unfamiliar thought processes. Journal of Experimental Social Psychology, 1975, 11, 261-270.

Scholtz, G. J. L., \& Ellis, M. J. Repeated exposure to objects and peers in a play setting. Journal of Experimental Child Psychology. 1975. 19. 448-455.

\section{Attitudes}

Barland, G. H. (Univ. of Utah, Salt Lake City, Utah 84112), \& RASKIN, D. C. An evaluation of field techniques in detection of deception. Psychophysiology, 1975, 12, 321-330.

Buckhout, R. (Brooklyn Coll., CUNY, Brooklyn, N.Y. 11210), Figueroa, D., \& Hoff, E. Eye witness identification: Effects of suggestion and bias in identification from photographs. Bulletin of the Psychonomic Society, 1975, 6, $71-74$.

Stephan. W. G. (Univ. of Texas, Austin, Tex. 78712). Actor vs observer: Attributions to behavior with positive or negative outcomes and empathy for the other role. Journal of Experimental Social Psychology, 1975, 11, 205-214.

\section{Social Influences}

Bernhardt, A. J. (Washburn Univ., Topeka, Kans. 66021). \& Forehand, R. The effects of labeled and unlabeled praise upon lower and middle class children. Journal of Experimental Child Psychology, 1975, 19, 536-543.

Blascovich, J. (Univ. of Nevada, Reno, Nev. 89507), Ginsburg, G. P., \& HowE, R. C. Blackjack and the risky shift. II: Monetary stakes. Journal of Experimental Social Psychology. 1975, 11, 224-232.

Bцоом, K. (Dalhousie Univ., Halifax, N.S., Canada), \& Esposito, A. Social conditioning and its proper control procedures. Journal of Experimental Child Psychology, 1975. 19. 209-222.

MorRis, W. N. (Dartmouth Coll., Hanover, N.H. 03755), \& MiLler, R. S. The effects of consensus-breaking and consensus- 
preempting partners on reduction of conformity. Journal of Experimental Social Psychology, 1975, 11, 215-223.

\section{Social Interaction}

Denney, D. R. (Univ. of Kansas, Lawrence, Kans. 66045). The effects of exemplary and cognitive models and self- rehearsal on children's interrogative strategies. Journal of Experimental Child Psychology, 1975, 19, 476-488.

Konecni, V. J. (Univ. of California, San Diego, P.O. Box 109 La Jolla, Calif. 92037), Libuser, L., Morton, H., \& EbBesEN, E. B. Effects of a violation of personal space on escape and helping responses. Journal of Experimental Social Psychology, 1975, 11, 288-299.

\section{ANIMAL LEARNING \& BEHAVIOR}

\section{DEVELOPMENT}

Genetics

Barr, G. A. (Dept. of Psychiat., Albert Einstein Coll. of Med., 1300 Morris Park Ave., Bronx, N.Y. 10461), Grbbons, J. L., \& MOYER, K. E. The relationship between mouse killing and intraspecific fighting in the albino rat. Behavioral Biology, 1975, 14, 201-208.

Horowitz, G. P., \& Whitney, G. (Florida State Univ., Tallahassee, Fla. 32306). Alcohol-induced conditioned aversion: Genotypic speciticity in mice (Mus musculus). Journal of Comparative and Physiological Psychology, 1975, 89, 340-346.

Randt, C. T. (Milbank Labs., Dept. of Neurol., Sch. of Med., New York Univ., 550 First Ave., New York, N.Y. 10016), Blizard, D. A., \& Friedman, E. Early life undernutrition and aggression in two mouse strains. Developmental Psychobiology, 1975, 8, 275-279.

YamaZaKi, K. (Dept. of Neuropsychiat., Fujita Gakuen Univ., 1-98 Kutukake, Toyoake, Aichi 470-11, Japan), TAJimI, T., OKUDA, K., \& NIIMI, Y. Skin potential activity in rats, cats, and primates (including man): A phylogenetic point of view. Journal of Comparative and Physiological Psychology, $1975,89,364-370$.

\section{Early Development}

Abel, E. L. (Rsch. Inst. on Alcoholism, 1021 Main St., Buffalo, N.Y. 14203). Emotionality in offspring of rats fed alcohol while nursing. Journal of Studies on Alcohol, 1975, 36, 654-658.

Bronstein, P. M. (Brooklyn Coll. of CUNY, Brooklyn, N.Y. 11210), Levine, M. J., \& Marcus, M. A rat's first bite: The nongenetic, cross-generational transfer of information. Journal of Comparative and Physiological Psychology, 1975, 89, 295-298.

Cornwell, C. A. (Princeton Univ., Princeton, N.J. 08540). Golden hamster pups adapt to complex rearing odors. Behavioral Biology, 1975, 14, 175-188.

Eastman, R. F., \& Mason, W. A. (Univ. of California Primate Rsch. Ctr., Davis, Calif. 95616). Looking behavior in monkeys raised with mobile and stationary artificial mothers. Developmental Psychobiology, 1975, 8, 213-221.

Ginsburg, H. J. (Southwest Texas State Univ., San Marcos, Tex. 78666). Defensive distance and immobility in young precocial birds (Gallus gallus). Developmental Psychobiology, $1975,8,281-285$.

Green, J. A. (Bucknell Univ., Lewisburg, Pa. 17837), \& ADKINS, E. K. The effects of prenatal and postnatal auditory stimulation on early vocalization and approach behavior in the Japanese quail (Coturnix coturnix japonica). Behaviour, 1975, 52, 145-154.

Grota, L. J. (Dept. of Psychiat., Univ. of Rochester Sch. of Med. \& Dent., 260 Crittendon Blvd., Rochester, N.Y. 14642). Effects of early experience and dexamethasone on adrenocortical reactivity. Developmental Psychobiology, 1975, 8, 251-259.

Mason, W. A. (Univ. of California Primate Rsch. Ctr., Davis, Calif. 65616), \& Berkson, G. Effects of maternal mobility on the development of rocking and other behaviors in rhesus monkeys: A study with artificial mothers. Developmental Psychobiology, 1975, 8, 197-211.
Maron, J. B. (Escola Paulista de Medicina, Departamento de Psicobiologia, Rua Botucatu, 86204023 Sao Paulo, Brazil), \& MASUR, J. Effects of pre and postweaning footshock on the later competitive behavior of rats in a straight runway. Behavioral Biology, 1975, 14, 209-220.

McGinn, M. D., \& Henry, K. R. (Univ. of California, Davis, Calif. 95616). Acute versus chronic acoustic deprivation: Effects on auditory evoked potentials and seizures in mice. Developmental Psychobiology, 1975, 8, 223-232.

Miller, D. E. (Dept. of Zool., Washington State Univ., Pullman, Wash. 91163), \& EmLen, J. T., JR. Individual chick recognition and family integrity in the ring-billed gull. Behaviour, 1975, 52, 123-144.

NAGY, Z. M. (Bowling Green State Univ., Bowling Green, Ohio 43403). Effect of drive level upon age of onset of 24-h retention of discriminated escape learning in infant mice. Bulletin of the Psychonomic Society, 1975, 6, 22-24.

RANDT, C. T. (Milbank Labs., Dept. of Neurol., Sch. of Med., New York Univ., 550 First Ave., New York, N.Y. 10016), \& Friedman, E. Early life undernutrition and aggression in two mouse strains. Developmental Psychobiology, 1975, 8, 275-279.

\section{Developmental Changes}

Diamond, M. C. (Dept. of Physiol.-Anat., Univ. of California, Berkeley, Calif. 94720), Johnson, R. E., \& Ingham, C. A. Morphological changes in the young, adult and aging rat cerebral cortex, hippocampus, and diencephalon. Behavioral Biology, 1975, 14, 163-174.

McLaughlin, L. J. (Gen. Med. Rsch., St. Louis VA Hosp., St. Lou is, Mo. 63125), Eller, H. D., \& Korol, B. Acquisition and retention of an avoidance response by rats of different ages. Developmental Psychobiology, 1975, 8, 233-239.

TeEs, R. C. (Univ. of British Columbia, Vancouver, B.C. V6T 1W5, Canada). The effects of neonatal striate lesions and visual experience on form discrimination in the rat. Canadian Journal of Psychology, 1975, 29, 66-72.

\section{MOTIVATION AND EMOTION}

Denny, M. S. (Michigan State Univ., East Lansing, Mich. 48824). The rat's long-term preference for complexity in its environment. Animal Learning \& Behavior, 1975, 3, 245-249.

Elliot,, R. (Dartmouth Coll., Hanover, N.H. 03755). Heart rate, activity, and activation in rats. Psychophysiology, 1975, 12, 298-305.

Seliger, D. L. (Rutgers Univ., Camden, N.J. 08102). Prenatal maternal d-amphetamine effects on emotionality and audiogenic seizure susceptibility of rat offspring. Developmental Psychobiology, 1975, 8, 261-268.

Sobrian, S. K., Weltman, M., \& Pappas, B. A. Neonatal locomotor and long-term behavioral effects of d-amphetamine in the rat. Developmental Psychobiology, 1975, 8, 241-250.

\section{Hunger and Thirst}

Capaldi, E. D. (Purdue Univ., West Lafayette, Ind. 47907), Hovancik, J. R., \& LAMB, E. O. The effects of strong irrelevant thirst on food-rewarded instrumental performance. Animal Learning \& Behavior, 1975, 3, 172-178.

CAREY, R. J. (VA Hosp., Irving Ave. \& University Pl., 
Svracuse, N.Y. 13210), Goodall, E. B.. \& Procopio, G. Motivational and neuroanatomical specificity of hypodipsia for aversive solutions produced by medial preoptic injury to the rat. Journal of Comparative and Physiological Psychology. $19^{-5}$. 89. 299-307.

Ellott. R. (Dartmouth Coll.. Hanover, N.H. 03755). Heart rate. activity. and activation in rats. Psychophysiology. 19?5. 12. 298-305.

Johnston. R. E. (Cornell Univ.. Ithaca, N.Y. 14850). Sexual excitation function of hamster vaginal secretion. Animal Le'aming \& Behavior, 1975, 3. 161-166.

Mason. W. A. (Univ. of California Primate Rsch Ctr.. Davis, Calif. 65616), \& Berkson. G. Effects of maternal mobility on the development of rocking and other behaviors in rhesus monkevs: A study with artiticial mothers. Developmental Psychobiology, 1975. 8. 197-211.

Wansley, R. A. (Dept. of Psychiat. \& Behav. Sci. Univ. of Oklahoma Hlth. Sci. Ctr., Oklahoma City, Okla. 73190). \& Holloway, F. A. Multiple retention deficits following one-trial appetitive training. Behavioral Biology, 1975. 14. 135-149.

\section{Physiological Factors}

Davidson. A. B. (Pharmacol. Dept.. Hoffman-La Roche, Inc. Nutler. N.J. 07110). \& Davis, D. J. Appetitive control of responding in the presence of free-food: Effects of d-amphetamine and fenfluramine. Bulletin of the Psychonomic Society, 1975. 6. 16-18.

Fenwick. S., Mikulka, P. J., \& Klein, S. B. (Old Dominion Univ.. Norfolk. Va. 23508). The effect of different levels of pre-exposure to sucrose on the acquisition and extinction of a conditioned aversion. Behavioral Biology, $1975,14,231-235$.

Thomka, M. L., Murphy, L. R., \& Brown, T. S. (DePaul Univ.. Chicago, 111. 60614). Limbic lesions and consummatory behavior in the rat. Bulletin of the Psychonomic Society, $1975,6,53-54$.

Wald, B. A., \& Cheney, C. D. (Utah State Univ. Logan, Utah 84322). Matching behavior and deprivation. Bulletin of the Psychonomic Society, 1975, 6, 4-6.

Zuckerman. D. C. (Hood Coll.. Frederick. Md. 21701). Motivational cues as determiners of stimulus control in rats Animal Learning \& Behavior. 1975, 3, 250-256.

\section{Fear and Immobility}

Ginsburg. H. J. (Southwest Texas State Univ., San Marcos, Tex. 78666). Defensive distance and immobility in young precocial birds (Gallus gallus). Developmental Psychobiology. 1975, 8, 281-285.

Goldstein, M. L. (Indiana Univ., Kokomo, Ind., 46901). An apparatus for the study of classical fear conditioning. Bulletin of the Psychonomic Society, 1975, 6, 106.

Marsh, R. R., Hoffman, H. S. (Bryn Mawr Coll., Bryn Mawr. Pa. 19010), Stitt, C. L., \& Schwartz, G. M. The role of small changes in the acoustic environment in modifying the startle reflex. Journal of Experimental Psychology: Animal Behavior Processes. 1975, 104, 235-244.

Maser. J. D. (Clin. Rsch. Branch, NIMH, 5600 Fishers Lane. Rockville, Md. 20852), Gallup, G. G., JR., \& Hicks, E. Tonic immobility in chickens: Possible involvement of monoamines. Journal of Comparative and Physiological Psychology, 1975, 89, 319-328.

NaSH R. F. (Marquette Univ., Milwaukee, Wis. 53233), $\&$ Gallup. G. G.. JR. Effect of different parameters of shock on tonic immobility. Behavior Research Methods \& Instrumentation, 1975. 7. 361-364.

\section{SOCIAL AND ABNORMAL BEHAVIOR}

Coок. R. (Dept. of Genetics \& Human Variation, La Trobe Lniv.. Victoria 3083. Australia). Courtship of Crosophila melanogaster: Rejection without extrusion. Behaviour, 1975. $52.155 .1^{-1}$
Figler, M. H. (Lab. of Psichobiol., Langley Porter Neuropsychiat. Inst. Univ. of California, San Francisco, Calif. 94143), Dyer. R. S.. Streckfus, C. F., \& Nardini, K. M. The establishment of dominance relationships in the jewel fish. Hemichromis bimaculatus (gill), as related to prior exposure to and configuration of visual cues. Behavioral Biology, 1975. 14. $241-245$.

Miller, D. E. (Dept. of Zool., Washington State Univ., Pullman, Wash. 91163). \& EMLEN, J. T.. JR. Individual chick recognition and family integrity in the ring-billed gull. Behaviour, 1975, 52, 123-144.

\section{Aggression}

BARr, G. A. (Dept. of Psychiat., Albert Einstein Coll of Med. 1300 Morris Park Ave., Bronx, N.Y. 10461), Gibbons, J. L., \& Moyer, K. E. The relationship between mouse killing and intraspecific fighting in the albino rat. Behavioral Biology, 1975, 14, 201-208.

Muller. P. G. (Utah State Univ., Logan. Utah 84322), \& CHENEY, C. D. The automatic recording of aggression in pigeons: A comparison of two methods with live targets. Behavior Research Methods \& Instrumentation, 1975, 7. $357-360$.

Myкyтоwycz, R. (Div. of Wildlife Rsch., CSIRO, Canberra, Australia), \& Hesterman, E. R. An experimental study of aggression in captive European rabbits, Oryctolagus cuniculus (L). Behavior, 1975, 52, 104-123.

Randt, C. T. (Milbank Labs., Dept. of Neurol., Sch. of Med., New York Univ., 550 First Ave., New York, N.Y. 10016), Blizard, D. A., \& Friedman, E. Early life undernutrition and aggression in two mouse strains. Developmental Psychobiology. 1975, 8, 275-279.

Rhoad, K. D. (Univ. of California, Santa Barbara, Calif. 93106), Kalat, J. W., \& Klopfer, P. H. Aggression and avoidance by Betta splendens toward natural and artificial stimuli. Animal Learning \& Behavior, 1975, 3, 271-276.

\section{SENSORY FUNCTIONS}

Tennant, W. A.. \& Bitterman, M. E. (Lab. of Sensory Sci., 1993 East-West Rd., Honolulu, Hawaii 96822). Extradimensional transfer in the discriminative learning of goldfish. Animal Learning \& Behavior, 1975, 3, 201-204.

\section{Vision}

Abramov. I. (Brooklyn Coll. of CUNY, Brooklyn, N.Y. 11210), \& Levine, M. W. On the lack of lateral inhibition within the receptive fields of goldfish retina! ganglion cells. Vision Research, 1975, 15, 791-798.

Bавкоғғ. H. (Bar-Ilan Univ., Ramat-Gan, Israel). The effect of light-deprivation on the adult electroretinogram. Vision Research, 1975, 15, 870-872.

BeATTY, D. D. (Dept. of Zool., Univ. of Alberta, Edmonton, Canada). Visual pigments of the American eel Anguilla rostrata. Vision Research, 1975, 15, 771-776.

Cerf-Beare, A. (Univ. of Maryland Baltimore County, Baltimore, Md. 21228), \& DEVoe, R. D. Automated analyses of circadian rhythm activity of small arthropods. Behavior Research Methods \& Instrumentation, 1975, 7, 339-347.

Creutzfeldt, O. D. (Dept. of Neurobiol., Max Planck Inst. for Biophysical Chem., P.O. Box 968, D-3400 Göttingen, West Germany), \& HegGelund, P. Neural plasticity in visual cortex of adult cats after exposure to visual patterns Science, 1975, 188, 1025-1027.

Davenport, R. K. (Yerkes Regional Primate Rsch. Ctr., of Emory Univ., Atlanta, Ga. 30322), Rogers, C. M., \& Russell. I. S. Cross-modal perception in apes: Altered visual cues and delay. Neuropsychologia, 1975, 13, 229-235.

Figler. M. H. (Dept. of Environmental Med.. Johns Hopkins Univ., Baltimore, Md. 21205), Dyer, R. S., Streckfus, C. F., d Nardini. K. M. The establishment of dominance 
relationships in the jewel tish, Hemichromis bimaculatus (gill), as related to prior exposure to and configuration of visual cues. Behavioral Biology, 1975, 14, 241-245.

Geary, N. D., \& Schrier, A. M. (Brown Univ., Providence, R.I. 02912). Eye movements of monkeys during performance of ambiguous cue problems. Animal Learning \& Behavior, 1975, 3, 167-171.

GreEN, D. G. (Dept. of Ophthalmol., Univ. of Michigan Med. Ctr., Ann Arbor, Mich. 48104), \& Siegel, I. M. Double branched flicker fusion curves from the all-rod skate retina. Science, 1975, 188, 1120-1122.

Green, J. A. (Bucknell Univ., Lewisburg, Pa. 17837), \& Adkins, E. $K$. The effects of prenatal and postnatal auditory stimulation on early vocalization and approach behavior in the Japanese quail (Cortunix coturnix japonica). Behaviour, 1975, 52, 145-154.

INGLE, D. (McLean Hosp., Belmont, Mass. 02178). Focal attention in the frog: Behavioral and physiological correlates. Science, 1975, 188, 1033-1035.

Levine, M. W. (Univ. of Illinois at Chicago Circle, Box 4348 , Chicago, Ill. 60680), \& ABramov, I. An analysis of spatial summation in the receptive fields of goldfish retinal ganglion cells. Vision Research, 1975, 15, 777-789.

Oscar-Berman, M. (Aphasia Rsch Ctr., Boston VA Hosp. 150 S. Huntington Ave., Boston, Mass. 02130). The effects of dorsolateral-frontal and ventrolateral-orbitofrontal lesions on spatial discrimination learning and delayed response in two modalities. Neuropsychologia, 1975, 13, 237-246.

Regan, D. (Dept. of Communication, Univ. of Keele, Keele Staffs., England), Schellart, N. A. M., Spekreiuse, H., \& VAN DEN Berg, T. J. T. P. Photometry in goldfish by electrophysiological recording: Comparison of criterion response method with heterochromatic flicker photometry. Vision Research, 1975, 15, 799-807.

REMÉ, C. Universitäts-Augenklinik Kantonsspital, CH-8006, Zürich, Switzerland), \& Niemeyer, G. Studies on the ultrastructure of the retina in the isolated and perfused feline eye. Vision Research, 1975, 15, 809-812.

Ridley, R. M. (Inst. of Psychiat., De Crespigny Park, London SE5 8AF, England), \& ETtLinger, G. Tactile and visuospatial discrimination performance in the monkey: The effects of total and partial posterior parietal removals. Neuropsychologia, 1975, 13, 191-206.

Sivak, J. G. (Sch. of Optometry, Univ., of Waterloo, Waterloo, Ont., Canada). Accommodative lens movements in fishes: Movement along the pupil axis vs movement along the pupil plane. Vision Research, 1975, 15, 825-828.

TEEs, R. C. Univ. of British Columbia, Vancouver, B.C. V6T 1W5, Canada). The effects of neonatal striate lesions and visual experience on form discrimination in the rat. Canadian Journal of Psychology, 1975, 29, 66-72.

WulfF, V. J. (Masonic Med. Rsch. Lab., Utica, New York, N.Y. 13503), StIEVE, H., \& FAHY, J. L. Dark adaptation and sodium pump activity in Limulus lateral eye retinular cells. Vision Research, 1975, 15, 759-765.

\section{Audition}

Marsh, R. R., Hoffman, H. S. (Bryn Mawr Coll., Bryn Mawr, Pa. 19010), Stitt, C. L., \& Schwartz, G. M. The role of small changes in the acoustic environment in modifying the startle reflex. Journal of Experimental Psychology: Animal Behavior Processes, 1975, 104, 235-244.

McGinn, M. D., \& Henry, K. R. (Univ. of California, Davis, Calif. 95616). Acute versus chronic acoustic deprivation: Effects on auditory evoked potentials and seizures in mice. Developmental Psychobiology, 1975, 8, 223-232.

Strelluf, R. H., \& Martin, R. C. (Univ. of Missouri, Kansas City, Mo. 64110). Test of aversiveness of a $39-\mathrm{kHz}$ tone to hooded rats. Bulletin of the Psychonomic Society, $1975,6,65-66$.
Waldrop, M. K. (Louisiana State Univ., Baton Rouge, La. 70803). Responses of human-reared monkeys to strange simian calls. Developmental Psychobiology, 1975, 8, 269-273.

Whitlow, J. W., JR. (Rockefeller Univ., New York, N.Y. 10021). Short-term memory in habituation and dishabituation. Journal of Experimental Psychology: Animal Behavior Processes, 1975, 104, 189-206.

\section{Lower Senses}

Cannon, D. S. (Mental Hlth. \& Behav. Sci. Serv., VA Hosp., Salt Lake City, Utah 84113), Berman, R. F., BAKER, T. B., \& Atkinson, C. A. Effect of preconditioning unconditioned stimulus experience on learned taste aversions. Journal of Experimental Psychology: Animal Behavior Processes, 1975, 104, 270-284.

CoRnwell, C. A. (Princeton Univ., Princeton, N.J. 08540). Golden hamster pups adapt to complex rearing odors. Behavioral Biology, 1975, 14, 175-188.

Johnston, R. E. (Cornell Univ., Ithaca, N.Y. 14850). Sexual excitation function of hamster vaginal secretion. Animal Learning \& Behavior, 1975, 3, 161-166.

Liu, C. N. (Depts. of Anat. Physical Med. \& Rehab., Univ. of Pennsylvania, Philadelphia, Pa. 19104), YU, J., Chambers, W. W., \& $\mathrm{HA}_{\mathrm{A}}, \mathrm{H}$. The role of the medial lemniscal and spinocervicothalamic pathways on tactile reactions in cats. Acta Neurogiologiae Experimentalis, 1975, 35, 149-157.

MARUNIAK, J. A. (Dept. of Zool., Univ. of Texas, Austin, Tex. 78712), Darney, K. J., JR., \& BRonson, F. H. Olfactory perception of the nonsocial environment by male house mice. Behavioral Biology, 1975, 14, 237-240.

Nigrosh, B., Slotnick, B. M. (American Univ., Washington, D.C. 20016), \& NEvin, J. A. Olfactory discrimination, reversal learning, and stimulus control in rats. Journal of Comparative and Physiological Psychology, 1975, 89, 285-294.

Ridley, R. M. (Inst. of Psychiat., De Crespigny Park, London SE5 8AT, England), \& ETTLINGER, G. Tactile and visuo-spatial discrimination performance in the monkey: The effects of total and partial posterior parietal removals. Neuropsychologia, 1975, 13, 191-206.

YAMAZAKI, K. (Dept. of Neuropsychiat., Fujita Gakuen Univ., 1-98 Kutukake, Toyoake, Aichi 470-11, Japan), TAJIMI, T., OKUDA, K., \& NirmI, Y. Skin potential activity in rats, cats, and primates (including man): A phylogenetic point of view. Journal of Comparative and Physiological Psychology, 1975, 89, 364-370.

\section{ANIMAL LEARNING AND RETENTION Conditioning}

Kimmel, H. D. (Univ. of South Florida, Tampa, Fla. 33620), RAY, R. L., \& KING, J. A television technique for quantifying conditioned and unconditioned responses of planarians. Behavior Research Methods \& Instrumentation, 1975, 7, 353-356.

\section{Classical Conditioning}

Cannon, D. S. (Mental Hith. \& Behav. Sci. Serv., VA Hosp., Salt Lake City, Utah 84113), Berman, R. F., BaKer, T. B., \& Atkinson, C. A. Effect of preconditioning unconditioned stimulus experience on learned taste aversions. Journal of Experimental Psychology: Animal Behavior Processes, 1975, 104, 270-284.

Odling-Smee, F. J. (Brunel Univ., Uxbridge, Middlesex, England). The role of background stimuli during Pavlovian conditioning. Quarterly Journal of Experimental Psychology, 1975, 27, 201-209.

Sheafor, P. J. (Dept. of Psychiat., Case Western Reserve Univ. Sch. of Med., Cleveland, Ohio 44106). "Pseudoconditioned" jaw movements of the rabbit reflect associations conditioned to contextual background cues. Journal of 
Experimental Psichology: Animal Behavior Processes, 1975. 104. $245-200$.

W Ald. B. A.. \& Cheney. C. D. (Utah State Univ.. Logan. L'tah 84322). Matching behavior and deprivation. Bulletin of the Psychonomic Society. 1975, 6. 4-6.

\section{Operant Conditioning}

Brown, R. T. (Univ. of North Carolina, Wilmington, N.C. 28401). Moditication of chicks' pecking preferences: Food imprinting or instrumental conditioning? Animal Learning \& Behavior. 1975. 3. 217-220.

Cohen, J. S. (Univ. of Windsor. Windsor, Ont., Canada N9B 3P4), \& QuirT, B. M. Cue utilization as a function of drive and operant response contingency. Bulletin of the Psychonomic Society. 1975, 6, 31-34.

Cohen. J. S. (Univ. of Windsor, Ont., Canada), \& Quirt, B. M. Drive level and cue utilization in a free operant situation with albino rats. Psychological Research. 1975, 37, 201-209.

Imada. H. (Kwansei Gakuin Univ., Nishinomiya, Japan), \& Oкамura, M. Some cues rats can use as predictors of danger and safety. Animal Learning \& Behavior, 1975, 3. 221-225.

Kendall, S. B. (Univ. of Western Ontario, London, Ontario NoA 5C2. Canada). Variations of two temporal parameters in observing response procedures. Animal Learning \& Behavior. 1975, 3, 179-185.

Zimmerman, J. (Indiana Univ. Sch. of Med., Indianapolis, Ind. 46202), \& HANFORD, P. V. Sustained mismatching performance in pigeons with chronically maintained conditioned reinforcement. Bulletin of the Psychonomic Society, 1975, 6. $102-104$.

\section{Conditioned Aversions}

Braveman, N. S. (Memorial Univ. of Newfoundland, St. John's, Nfld.. Canada). Relative salience of gustatory and visual cues in the formation of poison-based food aversions by guinea pigs (Cavia porcellus). Behavioral Biology, 1975. 14, 189-199.

Burdette. D. R.. Krantz, D. S., \& Amsel, A. (Univ. of Texas. Austin. 78712). Effects of inescapable shock in the rat: Learned helplessness or response competition. Bulletin of the Psychonomic Society, 1975, 6. 96-98.

Cannon. D. S. (Mental Hlth. \& Behav. Sci. Serv., VA Hosp., Salt Lake City, Ltah 84113), Berman. R. F., Baker. T. B., \& Atrinson, C. A. Effect of preconditioning unconditioned stimulus experience on learned taste aversions. Journal of Experimental Psichology: Animal Behavior Processes, 1975. 104. $270-284$.

Domjan, M. (Univ. of Texas, Austin. Tex. 78712). Poisoninduced neophobia in rats: Role of stimulus generalization of conditioned taste aversions. Animal Learning \& Behavior, 1975. 3. 205-211.

Davison. C. S. (Univ. of South Carolina. Columbia, S.C. 29208), \& HousE. W. J. Alcohol as the aversive stimulus in conditioned taste aversion. Bulletin of the Psychonomic Society, 1975, 6, 49-50.

FENwick, S. (Old Dominion Univ., Norfolk, Va. 23508), Mikulka. P. J., \& Klein, S. B. The effect of different levels of pre-exposure to sucrose on the acquisition and extinction of a conditioned aversion. Behavioral Biology, 1975, 14, 231-235.

Frumkin, K. (Reprints from Peter M. Milner, McGill Univ., P.O. Box 6070, Montreal 101, P.Q.. Canada). Failure of sodium- and calcium-deficient rats to acquire conditioned taste aversions to the object of their specific hunger. Journal of Comparative and Physiological Psychology, 1975, 89, 329-339.

Horowitz, G. P., \& Whitney, G. Alcohol-induced conditioned aversion: Genotypic specificity in mice (Mus musculus). Journal of Comparative and Physiological Psychology, 1975, 89. 340-346.

Streluff, R. H., \& Martin, R. C. (Univ. of Missouri, Kansas City. Mo. 64110). Test of aversiveness of a $39-\mathrm{kHz}$ tone to hooded rats. Bulletin of the Psychonomic Society, $1975.6 .65-66$.

\section{Discrimination Learning}

Brown, R. T. (Univ. of North Carolina. Wilmington, N.C. 28401). Modification of chicks' pecking preferences: Food imprinting or instrumental conditioning? Animal Learning \& Behavior, 1975, 3. 217-220.

Geary, N. D., \& Schrier, A. M. (Brown Univ., Providence, R.I. 02912). Eye movements of monkeys during performance of ambiguous cue problems. Animal Learning \& Behavior, 1975. 3. 167-171.

Greenway, A. P. (Univ. of Aberdeen. Old Aberdeen, Scotland $A B 9$ 2UB). Amount of training and reversal learning with singly presented stimuli in the rat. Animal Learning \& Behavior, 1975, 3, 235-238.

Hall, G. (Univ. of Sussex. Brighton. England). An analysis of positive general transfer in discrimination learning in the rat. Animal Learning \& Behavior. 1975, 3, 212-216.

Hamlin, P. H. (Virginia Polytech. Inst. \& State Univ., Blacksburg, Va. 24061). Observing responses as an index of attention in chickens. Journal of Experimental Psychology: Animal Behavior Processes, 1975, 104, 221-234.

Hochrauser. M. (West Virginia State Coll.. Institute, W. Va. 25112), \& Fowler, H. Cue effects of drive and reward as a function of discrimination difficulty: Evidence against the Yerkes-Dodson law. Journal of Experimental Psychology: Animal Behavior Processes, 1975, 104, 261-269.

MacPhail, E. M. (Lab. of Exptl. Psychol.. Univ. of Sussex, Brighton BN1 9QG, England). Behavioural contrast in discrete-trial discriminations: Effects of non-reinforcement. Quarterly Journal of Experimental Psychology, 1975, 27, 259-271.

Mandler, J. M. (Univ. of California, San Diego, La Jolla, Calit. 92037). \& Goldberg, J. Changes in response to $\mathrm{S}+$ and $\mathrm{S}$ - during acquisition and overtraining of simultaneous discriminations in rats. Animal Learning \& Behavior, 1975, 3. $226-234$.

Maroni, J. B. (Escola Paulista de Medicina, Departamento de Psicobiologia. Rua Botucatu, 86204023 Sao Paulo, Brazil). \& MASUR. J. Effects of pre and postweaning footshock in the later competitive behavior of rats in a straight runway. Behavioral Biology. 1975, 14, 209-220.

NAGY, Z. M. (Bowling Green State Univ., Bowling Green, Ohio 43403). Effect of drive level upon age of onset of 24-h retention of discriminated escape learning in infant mice. Bulletin of the Psychonomic Society, 1975, 6, 22-24.

Nigrosh, B. J., Slotnick, B. M. (American Univ., Washington, D.C. 20016), \& Nevin, J. A. Olfactory discrimination, reversal learning, and stimulus control in rats. Journal of Comparative and Physiological Psychology, 1975, 89, 285-294.

Oscar-Berman, M. (Aphasia Rsch. Ctr., Boston VA Hosp., 150 S. Huntington Ave., Boston, Mass. 02130). The effects of dorsolateral-frontal and ventrolateral-orbitofrontal lesions on spatial discrimination learning and delayed response in two modalities. Neuropsychologia, 1975, 13, 237-246.

REESE, N. C. (Univ. of Southern Mississippi, Hattiesburg, Miss. 39401). Imprinting as an independent variable in the modeling of a low-probability behavior in chicks. Bulletin of the Psychonomic Society, 1975, 6, 28-30.

Tennant, W. A., \& Bitterman, M. E. (Lab. of Sensory Sci., 1993 East-West Rd., Honolulu, Hawaii 96822). Extradimensional transfer in the discriminative learning of gold tish. Animal Learning \& Behavior, 1975, 3, 201-204.

Zuckerman, D. C. (Hood Coll., Frederick, Md. 21701). Motivational cues as determiners of stimulus control in rats. Animal Learning \& Behavior, 1975, 3, 250-256.

\section{Maze and Runway Behavior}

Brister, P. D.. \& Melvin, K. B. (Univ. of Alabama, University. Ala. 35486). Self-punitive avoidance behavior in the mouse. Animal Learning \& Behavior, 1975, 3, 196-200.

Capaldi, E. D. (Dept. of Psychol. Sci.. Purdue Univ., 
West Lafayette, Ind. 47907), Hovancik, J. R., \& LAMB, E. O. The effects of strong irrelevant thirst on foodrewarded instrumental performance. Animal Learning \& Behavior, 1975, 3, 172-178.

Davis, S. F. (Austin Peay State Univ., Clarksville, Tenn. 37040), \& SEAGo, J. D. Differential conditioning as a function of surgical anosmia. Bulletin of the Psychonomic Society, $1975,6,10-12$.

Delude, L. A. (Univ. of Lethbridge, Lethbridge, Alta., Canada T1K 3M4). Punishment of abient responding with and without a non-punished alternative available: A conflictresolution view. Canadian Journal of Psychology, 1975, 29, 11-21.

Gatti, S. V., Pais, N., \& Weeks, J. R., JR. (Reprints from Joseph J. Franchina, Virginia Polytech. Inst. \& State Univ., Blacksburg, Va. 24061). Effects of reinstatement procedures on retention of differential appetitive responding. Bulletin of the Psychonomic Society, 1975, 6, 57-60.

Hovsepian, W. (Temple Univ., Philadelphia, Pa. 19122), \& McClanahan, N. Vibrissae amputation in mice and completion of a learned food-acquisition task. Bulletin of the Psychonomic Society, 1975, 6, 69-70.

McHose, J. H. (Southern Illinois Univ., Carbondale, Ill. 62901), \& Peters, D. P. Partial reward, the negative contrast effect. and incentive averaging. Animal Learning \& Behavior, 1975, 3, 239-244.

Wansley, R. A. (Dept. of Psychiat. \& Behav. Sci., Univ. of Oklahoma Hith Sci. Ctr., Oklahoma City, Okla. 73190), \& Holloway, F. A. Multiple retention deficits following one-trial appetitive training. Behavioral Biology, 1975, 14, 135-149.

\section{Avoidance and Punishment}

Arabian, J. M. (Connecticut Coll., New London, Conn. 06320),\& Desiderato, O. Preference for signaled shock: A test of two hypotheses. Animal Learning \& Behavior, 1975, 3, 191-195.

Brauth, S. E. (Dept. of Psychiat. \& Behav. Sci., SUNY, Stony Brook, N.Y. 11790), \& Coons, E. E. Correlation of overt escape behavior, multiunit thalamic activity, and midbrain lemniscal stimulation in rats. Journal of Comparative and Physiological Psychology, 1975, 89, 371-378.

Brister, P. D., \& Melvin, K. B. (Univ. of Alabama, University, Ala. 35486). Self-punitive avoidance behavior in the mouse. Animal Learning \& Behavior, 1975, 3, 196-200.

Burdette, D. R., Krantz, D. S., \& Amsel, A. Effects of inescapable shock in the rat: Learned helplessness or response competition. Bulletin of the Psychonomic Society. $1975,6,96-98$.

Cappell, H. (Addiction Rsch. Fdtn., 33 Russell St. Toronto, Ont., M5S 2S1, Canada), LeBlanc, A. E.. \& Herling, S. Modification of the punishing effects of psychoactive drugs in rats by previous drug experience. Journal of Comparative and Physiological Psychology, 1975. 89. $347-356$.

Delude, L. A. (Univ. of Lethbridge, Lethbridge, Alta. Canada T1K 3M4). Punishment of abient responding with and without a non-punished alternative available: A conflictresolution view. Canadian Journal of Psychology, 1975, 29. 11-21.

Franchina, J. J. (Virginia Polytech. Inst. \& State Univ.. Blacksburg, Va. 24061), Schindele, T. E., \& Ritenour, K. R. Effects of retraining following response prevention on extinction of escape behavior. Animal Learning \& Behavior, 1975, 3, 186-190.

Freeman, J., \& Badia, P. (Bowling Green State Univ., Bowling Green, Ohio 43403). Do rats prefer information about shock intensity? Bulletin of the Psychonomic Society, $1975,6,75-78$.

ImAdA, H. (Kwansei Gakuin Univ., Nishinomiya, Japan), \& OKamura, M. Some cues rats can use as predictors of danger and safety. Animal Learning \& Behavior, 1975, 3, 221-225.
Mclaughlin, L. J. (Gen. Med. Rsch., St. Louis VA Hosp., St. Louis, Mo. 63125), Eller, H. D., \& Korol, B. Acquisition and retention of an avoidance response by rats of different ages. Developmental Psychobiology, 1975, 8, 233-239.

Modaresi, H. A. (Univ. of California, Riverside, Calif. 92502), Coe, W. V., \& Glendenning, B. J. An efficient oneand two-way avoidance apparatus capable of producing idential one- and two-way avoidance performance. Behavior Research Methods \& Instrumentation, 1975, 7, 348-350.

NaGY, Z. M. (Bowling Green State Univ., Bowling Green, Ohio 43403). Effect of drive level upon age of onset of 24-h retention of discriminated escape learning in infant mice. Bulletin of the Psychonomic Society, 1975, 6, 22-24.

\section{Reinforcement}

Conen, J. S. (Univ. of Windsor, Windsor, Ont., Canada N9B 3P4), \& QuirT, B. M. Cue utilization as a function of drive and operant response contingency. Bulletin of the Psychonomic Society, 1975, 6, 31-34.

Cohen, J. S. (Univ. of Windsor, Ont., Canada), \& Quirt, B. M. Drive level and cue utilization in a free operant situation with albino rats. Psychological Research, 1975, 37, 201-209.

Kendall, S. B. (Univ. of Western Ontario, London, Ont. N6A 5C2, Canada). Variations of two temporal parameters in observing response procedures. Animal Learning \& Behavior, 1975, 3, 179-185.

MacPhail, E. M. (Lab. of Exptl. Psychol., Univ. of Sussex, Brighton, BN1 9QG, England). Behavioural contrast in discretetrial discriminations: Effects of non-reinforcement. Quarterly Journal of Experimental Psychology, 1975, 27, 259-271.

Mclaughlin, L. J. (Gen. Med. Rsch., St. Louis VA Hosp., St. Louis, Mo. 63125), Eller, H. D., \& Korol, B. Acquisition and retention of an avoidance response by rats of different ages. Developmental Psychobiology, 1975, 8, 233-239.

McSweeney, F. K. (Washington State Univ., Pullman, Wash. 99163). Concurrent schedule responding as a function of body weight. Animal Learning \& Behavior, 1975, 3, 264-270.

WANSLEY, R. A. (Dept. of Psychiat. \& Behav. Sci., Univ. of Oklahoma Hlth Sci. Ctr., Oklahoma City, Okla. 73190), \& Holloway, F. A. Multiple retention deficits following one-trial appetitive training. Behavioral Biology, 1975, 14, 135-149.

Zimmerman, J. (Indiana Univ. Sch. of Med., Indianapolis, Ind. 46202), \& HANFORD, P. V. Sustained mismatching performance in pigeons with chronically maintained conditioned reinforcement. Bulletin of the Psychonomic Society, 1975, 6. 102-104.

Reward

Capaldi. E. D. (Purdue Univ., West Lafayette, Ind. 47907), Hovancik, J. R., \& LAMB, E. O. The effects of strong irrelevant thirst on food-rewarded instrumental performance. Animal Learning \& Behavior. 1975, 3, 172-178.

Cox, W. M. (Univ. of Oregon Hlth. Sci. Ctr., Portland, Oreg. 97201), \& BLACK, R. W. Shifts in maynitude of dclayed and immediate reward. Bulletin of the Psychonomic Society, 1975, 6, 35-38.

Gatti, S. V., Pais, N., \& Weeks, J. R., JR. (Reprints from Joseph J. Franchina, Virginia Polytech. Inst. \& State Univ., Blacksburg, Va. 24061). Effects of reinstatement procedures on retention of differential appetitive responding. Bulletin of the Psychonomic Society, 1975, 6, 57-60.

Hochrauser, M. (West Virginia State Coll., Institute, W. Va. 25112), \& Fowler, H. Cue effects of drive and reward as a function of discrimination difficulty: Evidence against the Yerkes-Dodson law. Journal of Experimental Psychology: Animal Behavior Processes, 1975, 104, 261-269.

McHose. J. H. (Southern Illinois Univ., Carbondale, Ill. 62901), \& Peters, D. P. Partial reward, the negative contrast effect. 
and incentive averaging. Animal Learning \& Beharior. $14^{-5}$. 3. 234-244.

White. N. (McGill Univ., Montreal, P.Q.. Canada). Effects of anterior medial forebrain bundle lesions on self-stimulation with two different operant responses. Behavioral Biology' $19^{-5}$. 14. 221-230.

\section{Retention}

Grant, D. S. (Univ. of Western Ontario, London, Ont., Canada). Proactive interference in pigeon short-term memory.
Journal of Experimental Psychology: Animal Behavior Process, 1975, 104, 207-220.

Hinderliter, C. F.. Webster, T., \& Riccio, D. C. (Kent State Unis.. Kent. Ohio 44242). Amnesia induced by hypothermia as a function of treatment-test interval and recooling in rats. Animal Learning \& Behavior, 1975, 3, 257-263.

Whitlow, J. W., JR. (Rockefeller Univ.. New York, N.Y. 10021). Short-term memory in habituation and dishabituation. Journal of Experimental Psychology: Animal Behavior Processes, 1975, 104, 189-206.

\section{PHYSIOLOGICAL PSYCHOLOGY}

\section{BRAIN FUNCTIONS}

Creutzfeldt, O. D. (Dept. of Neurobiol., Max Planck Inst. for Biophys. Chem.. P.O. Box 968. D-3400 Göttingen. West Germany), \& Heggelund, P. Neural plasticity in visual cortex of adults cats after exposure to visual patterns. Science. 1975, 188, 1025-1027.

Davis. S. F. (Austin Peay State Univ., Clarksville, Tenn. 37040). \& SEAGO. J. D. Differential conditioning as a function of surgical anosmia. Bulletin of the Psychonomic Society, 1975. 6. $10-12$.

Diamond, M. C. (Dept. of Physiol.-Anat., Univ. of California. Berkeley. Calif. 94720), Johnson, R. E., \& Ingham. 'C. A Morphological changes in the young. adult and aging rat cerebral cortex. hippocampus, and diencephalon. Behavioral Biology, 1975, 14, 163-174.

Hicks. R. E. (SLNY. 14 Washington Are.. Albany. N.Y. 12222). Assmmetry of bilateral transfer. American Journal of Psichologi. 1974. 87. 667-674.

Ingle. D. (McLean Hosp.. Belmont. Mass. 02178). Focal attention in the frog: Behavioral and physiological correlates. Science. 1975, 188, 1033-1035.

KNÜSEl. A. (Dept. of Pharmacol. \& Biochem.. Sch. of Vet. Med., Lniv. of Zürich. Winterthurerstr. 200, CH-8057, Zürich. Switzerland). Heidelberger. R.. \& Kuenzle. C. C. Is gene activation in brain neurons the basis of memory and learning? Bulletin of the Psychonomic Society. 1975. 6. 99-101.

NADEL. L. (Cerebral Functions Grp., Dept. of Anat., Univ. Coll.. London. England), O'Keefe, J., \& Black, A. Slam on the brakes: A critique of Altman. Brunner. and Bayer's response-inhibition model of hippocampal function. Behavioral Biology. 1975. 14, 151-162.

Provins. K. A. (Australian National Univ., Canberra, A.C.T.. Australia). \& Jfeves. M. A. Hemisphere differences in response time to simple auditory stimuli. Neuropsychologia. 1975. 13. 207-211.

White, K. G. (Victoria Univ., Wellington, New Zealand). \& Silver. A. B. Cerebral hemispheres serve as two channels for visual information processing. Bulletin of the Psychonomic Society, 1975, 6, 51-52.

\section{Lesions}

Liv. C. N. (Depts. of Anat. Phys. Med., \& Rehab., Inst. of Neurol. Sci., Univ. of Pennsylvania, Philadelphia, Pa. 19104), Yu, J.. Chambers, W. W., \& Ha, H. The role of the median lemniscal and spinocervicothalamic pathways on tactile reactions in cats. Acta Neurobiologiue Experimentalis, 1975, 35, 149-157.

\section{Cortex}

Oscar-Berman, M. (Aphasia Rsch. Ctr., Boston VA Hosp., 150 S. Huntington Ave., Boston, Mass. 02130). The effects of dorsolateral-frontal and ventrolateral-orbitofrontal lesions on spatial discrimination learning and delayed response in two modalities. Neuropsychologia, 1975, 13, 237-246.
Ridley, R. M. (Inst. of Psychiat., De Crespigny Park, London SE5 8AF, England), \& Ettlinger, G. Tactile and visuospatial discrimination performance in the monkey: The effects of total and partial posterior parietal removals. Neuropsichologia, 1975, 13, 191-206.

TEEs, R. C. (Univ. of British Columbia, Vancouver, B.C. V67 1W5. Canada). The effects of neonatal striate lesions and visual experience on form discrimination in the rat. Canadian Journal of Psychology. 1975, 29, 66-72.

Limbic System

CAREY. R. J. (VA Hosp.. Irving Ave., \& University Pl., Syracuse, N.Y. 13210). Goodall, E. B., \& Procopio, G. Motivational and neuroanatomical specificity of hypodipsia for aversive solutions produced by medial preoptic injury to the rat. Journal of Comparative and Physiological Psychology. 1975, 89. 299-307.

Goldstein. M. L. (Indiana Univ., Kokomo, Ind. 46901). A simple method for making small lesions in the limbic system of the white rate. Bulletin of the Psychonomic Society. 1975, 6, 67-68.

ThomкA, M. L., Murphy, L. R., \& Brown, T. S. Limbic lesions and consummatory behavior in the rat. Bulletin of the Psychonomic Society. 1975. 6. 53-54.

W HITE, N. (McGill Univ., Montreal, P.Q., Canada). Effects of anterior medial forebrain bundle lesions on self-stimulation with two different operant responses. Behavioral Biology, 1975. 14. $221-230$.

\section{Electrical Activity}

Baвkoff, H. (Bar-Ilan Univ., Ramat-Gan, Israel). The effect of light-deprivation on the adult electroretinogram. Vision Research, 1975, 15, 870-872.

Brauth, S. E. (Dept. of Psychiat. \& Behav. Sci., SUNY, Stony Brook, N.Y. 11790), \& Coons, E. E. Correlation of overt escape behavior, multiunit thalamic activity, and midbrain lemniscal stimulation in rats. Journal of Comparative and Physiological Psychology, 1975, 89. 371-378.

Dumas, R. (Stantord Univ., Stanford, Calif. 94305), \& Morgan, A. EEG asymmetry as a function of occupation, task, and task difficulty. Neuropsychologia, 1975, 13, 219-228.

HoRd, D. (Nav. Hlth. Rsch. Ctr., San Diego, Calif. 92152). Common mode rejection techniques in conjugate eye movement recording during sleep. Psychophysiology, 1975, 12. 351-355.

McGinn, M. D., \& Henry, K. R. (Univ. of California, Davis, Calif. 95616). Acute versus chronic acoustic deprivation: Effects on auditory evoked potentials and seizures in mice. Developmental Psychobiology, 1975, 8, 223-232.

Regan, D. (Dept. of Communication, Univ. of Keele, Keele, Staffs.. England). Schellart, N. A. M., Spekreijse, H., \& VAN DEN Berg. T. J. T. P. Photometry in goldfish by electrophysiological recording: Comparison of criterion response method with heterochromatic flicker photometry. Vision Research, 1975, 15. 799-807. 
Valle, R. S. (Duquesne Univ., Pittsburgh, Pa. 15219), \& Levine, J. M. Expectation effects in alpha wave control. Psychophysiology, 1975, 12, 306-309.

Wевв, W. B. (Univ. of Florida, Gainesville, Fla. 32601), \& Agnew, H. W., JR. Are we chronically sleep deprived? Bulletin of the Psychonomic Society, 1975, 6, 47-48.

Whitlow, J. W., JR. (Rockefeller Univ., New York, N.Y. 10021). Short-term memory in habituation and dishabituation. Journal of Experimental Psychology: Animal Behavior Processes. 1975, 104, 189-206.

Wilson, J. R. (Mental Hith. Rsch. Inst., Univ. of Michigan, Ann Arbor, Mich. 48104), \& DiCARA, L. V. Influence of neuromuscular blocking drugs on recovery of skeletal electromyographic activity in the rat. Psychophysiology, 1975, 12, 249-253.

\section{PHYSIOLOGICAL EFFECTS}

Braveman, N. S. (Memorial Univ. of Newfoundland, St. John's, Nfld., Canada). Relative salience of gustatory and visual cues in the formation of poison-based food aversions by guinea pigs (Cavia porcellus). Behavioral Biology, 1975, 14, 189-199.

Domsan, M. (Univ. of Texas, Austin, Tex. 78712). Poisoninduced neophobia in rats: Role of stimulus generalization of conditioned taste aversions. Animal Learning \& Behavior. 1975, 3, 205-211.

KnÜSEl, A. (Dept. of Pharmacol. \& Biochem., Sch. of Vet. Med., Univ. of Zürich, Winterthurerstr. 260, CH-8057, Zürich, Switzerland), Heidelberger, R., \& Kuenzle, C. C. Is gene activation in brain neurons the basis of memory and learning? Bulletin of the Psychonomic Society, 1975, 6, 99-101.

\section{Drug Effects}

Abel, E. L. (Rsch. Inst. on Alcoholism, 1021 Main St., Buffalo, N.Y. 14203). Emotionality in offspring of rats fed alcohol while nursing. Journal of Studies on Alcohol, 1975 , 36, 654-658.

Cappel, H. (Addiction Rsch. Fdtn., 33 Russell St., Toronto, Ont., M5S 2S1, Canada), LeBlanc, A. E., \& Herling, S. Modification of the punishing effects of psychoactive drugs in rats by previous drug experience. Journal of Comparative \& Physiological Psychology, 1975, 89, 347-356.

Davidson, A. B. (Pharmacol. Dept., Hoffman-LäRoche, Inc., Nutley, N.J. 07110), \& Davis, D. J. Appetitive control of responding in the present of free food: Effects of d-amphetamine and fenfluramine. Bulletin of the Psychonomic Society, 1975, 6 , 16-18.

Davison, C. S. (Univ. of South Carolina, Columbia, S.C. 29208), \& House, W. J. Alcohol as the aversive stimulus in conditioned taste aversion. Bulletin of the Psychonomic Society, 1975, 6, 49-50.

Grota, L. J. (Dept. of Psychiat., Univ. of Rochester Sch. of Med. \& Dent., 6260 Crittendon Blvd., Rochester, N.Y. 14642). Effects of early experience and dexamethasone on adrenocortical reactivity. Developmental Psychobiology, 1975, 8, 251-259.

HahN, W. W. (Univ. of Denver, Denver, Colo. 80210), SCHWARTz, M. L., \& SAPper, H. V. The effects of d-tubocurarine chloride and respiratory settings on heart rate and blood gas composition in the albino rat. Psychophysiology, 1975, 12, 331-338.

Horowitz, G. P., \& Whitney, G. (Florida State Univ., Tallahassee, Fla. 32306). Alcohol-induced conditioned aversion: Genotypic specificity in mice (Mus musculus). Journal of Comparative and Physiological Psychology, 1975, 89, 340-346.

Jones, B. P. (Boston VA Hosp., 150 S. Huntington Ave. Boston, Mass. 02130), Moskowitz, H. R., \& Butrers, N. Olfactory discrimination in alcoholic Korsakoff patients. Neuropsychologia, 1975, 13, 173-179.
Lyon, R. J. (Univ. of Guelph, Guelph, Ont., Canada N1G 2W1), Tong, J. E., Leigh, G., \& Clare, G. The influence of alcohol and tobacco on the components of choice reaction time. Journal of Studies on Alcohol, 1975, 36, 587-596.

MASER, J. D. (Clin. Rsch. Branch, NIMH, 5600 Fishers Lane, Rockville, Md. 20852), Gallup, G. G., JR., \& Hicks, L. E. Tonic immobility in chickens: Possible involvement of monoamines. Journal of Comparative and Physiological Psychology, 1975, 89, 319-328.

Seliger, D. L. (Rutgers Univ., Camden, N.J. 08102). Prenatal maternal d-amphetamine effects on emotionality and audiogenic seizure susceptibility of rat offspring. Developmental Psychobiology, 1975, 8, 261-268.

Sobrian, S. K., Weltman, M., \& Pappas, B. A. (Carleton Univ., Ottawa, Ont., K1S 5B6, Canada). Neonatal locomotor and long-term behavioral effects of d-amphetamine in the rat. Developmental Psvchobiology, 1975, 8, 241-250.

Wilson, J. R. (MHRI, Univ. of Michigan, Ann Arbor, Mich. 48104), \& DiCARA, L. V. Influence of neuromuscular blocking drugs on recovery of skeletal electromyographic activity in the rat. Psychophysiology, 1975, 12, 249-253.

\section{Stress Effects}

Barland, G. H. (Univ. of Utah, Salt Lake City, Utah 84112), \& RASKIN, D. C. An evaluation of field techniques in detection of deception. Psychophysiology, 1975, 12, 321-330.

Goodenough, D. R. (Div. of Psychol. Studies, Ed. Testing Serv., Princeton, N.J. 08540), Witkin, H. A., Koulack, D., \& Cohen, H. The effects of stress films on dream affect and on respiration and eye-movement activity during rapideye-movement sleep. Psychophysiology, 1975, 12, 313-320.

Grota, L. J. Dept. of Psychiat., Univ. of Rochester Sch. of Med. \& Dent., 6260 Crittendon Blvd., Rochester, N.Y. 14642). Effects of early experience and dexamethasone on adrenocortical reactivity. Developmental Psychobiology, 1975, 8, 251-259.

Hinderlite R, C. F., Webster, T., \& Riccio, D. C. (Kent State Univ., Kent, Ohio 44242). Amnesia induced by hypothermia as a function of treatment-test interval and recooling in rats. Animal Learning \& Behavior. 1975, 3, 257-263.

Lovallo, W. (Dept. of Psychiat. \& Behav. Sci., Univ. of Oklahoma Hlth. Sci. Ctr., P.O. Box 26901, 800 N.E. 13th St., Oklahoma City, Okla. 73190). The cold pressor test and autonomic function: A review and integration. Psychophysiology, 1975, 12, 268-282.

Maroni, J. B. (Escola Paulista de Medicina, Departamento de Psicobiologia, Rua Botucatu, 86204023 Sao Paulo, Brazil), \& MASUR, J. Effects of pre and postweaning footshock on the later competitive behavior of rats in a straight runway. Behavioral Biology, 1975, 14, 209-220.

\section{Autonomic Effects}

Bell, I. R., \& Schwartz, G. E. (Dept. of Psychol. \& Soc. Rel., Harvard Univ., 1544 William James Hall, Cambridge, Mass. 02138). Voluntary control and reactivity of human heart rate. Psychophysiology, 1975, 12, 339-348.

Berg, W. K., Jackson, J. C., \& Graham, F. K. (Univ. Hosps., Madison, Wis. 53706). Tone intensity and rise-decay time effects on cardiac responses during sleep. Psychophysiology, 1975, 12, 254-261.

Elliotr, R. (Dartmouth Coll., Hanover, N.H. 03755). Heart rate, activity, and activation in rats. Psychophysiology, 1975, 12, 298-305.

Graham, F. K. (Univ. Hosps., Madison, Wis. 53706). The more or less startling effects of weak prestimulation. Psychophysiology, 1975, 12, 238-248. 
HARE, R. D. (Univ. of British Columbia, Vancouver, Canada V6T 1W5), \& Blevings, G. Conditioned orienting and defensive responses. Psychophysiology, 1975, 12, 289-297.

Hovsepian, W. (Temple Univ., Philadelphia, Pa. 19122), \& McClan aHaN, $N$. Vibrissae amputation in mice and completion of a learned food-acquisition task. Bulletin of the Psychonomic Society', 1975, 6, 69-70.

Kaiser, D. N., \& Sandman, C. A. (Ohio State Univ., Columbus, Ohio 43210). Physiological patterns accompanying complex problem solving during warning and nonwarning conditions. Journal of Comparative and Physiological Psychology, 1975, 89, 357-363.

Krupski, A. (Grad. Sch. of Ed., UClA, 450 Hilgard Ave., Los Angeles, Calif. 90024). Heart rate changes during a fixed reaction time task in normal and retarded adult males. Psychophysiology, 1975, 12, 262-267.
Lovallo, W. (Dept. of Psychiat. \& Behav. Sci., Univ. of Oklahoma Hlth Sci. Ctr., P.O. Box 26901, 800 N.E. 13th St., Oklahoma City, Okla. 73190). The cold pressor test and autonomic function: A review and integration. Psychophysiology: 1975, 12. 268-282.

Wald. A. (New York Univ. Med. Ctr., Dept. of Neurosurg.. 550 First Ave., New York, N.Y. 10016), \& HarRIson, L. B. Oxygen consumption and heart rate: Changes and relationships in static work. Ergonomics, 1975, 18, 299-309.

Weiss. T. (Dept. of Psychiat., Univ. of Pennsylvania, Philadelphia. Pa. 19174), \& Engel, B. T. Evaluation of an intra-cardiac limit of learned heart rate control. Psychophy'siology', 1975, 12, 310-312. 